\title{
Retail Store Operations and Food Waste
}

\author{
(published in the Journal of Cleaner Production in 2018)
}

Christoph Teller [corresponding author, University of Surrey, Guildford, Surrey, GU2 7XH, United Kingdom. [T] ++ 44148368 3981, [E] c.teller@surrey.ac.uk]

Christina Holweg [WU Vienna University of Economics and Business, Welthandelsplatz 1, 1020 Vienna, Austria, [T] ++43 131336 46206, [E] christina.holweg@wu.ac.at]

Gerald Reiner [University of Klagenfurt, Universitätsstraße 65-67, 9020 Klagenfurt, Austria, $[\mathrm{T}]++43$ (0) 4632700 4072, [E] gerald.reiner@aau.at]

Herbert Kotzab [University of Bremen, Wilhelm-Herbst-Straße 12, 28359 Bremen, Germany, [T] +49 421 218 66981, [E] kotzab@uni-bremen.de]

\section{Graphical Abstract}

\section{FOOD WASTE \\ IN RETAIL STORES}

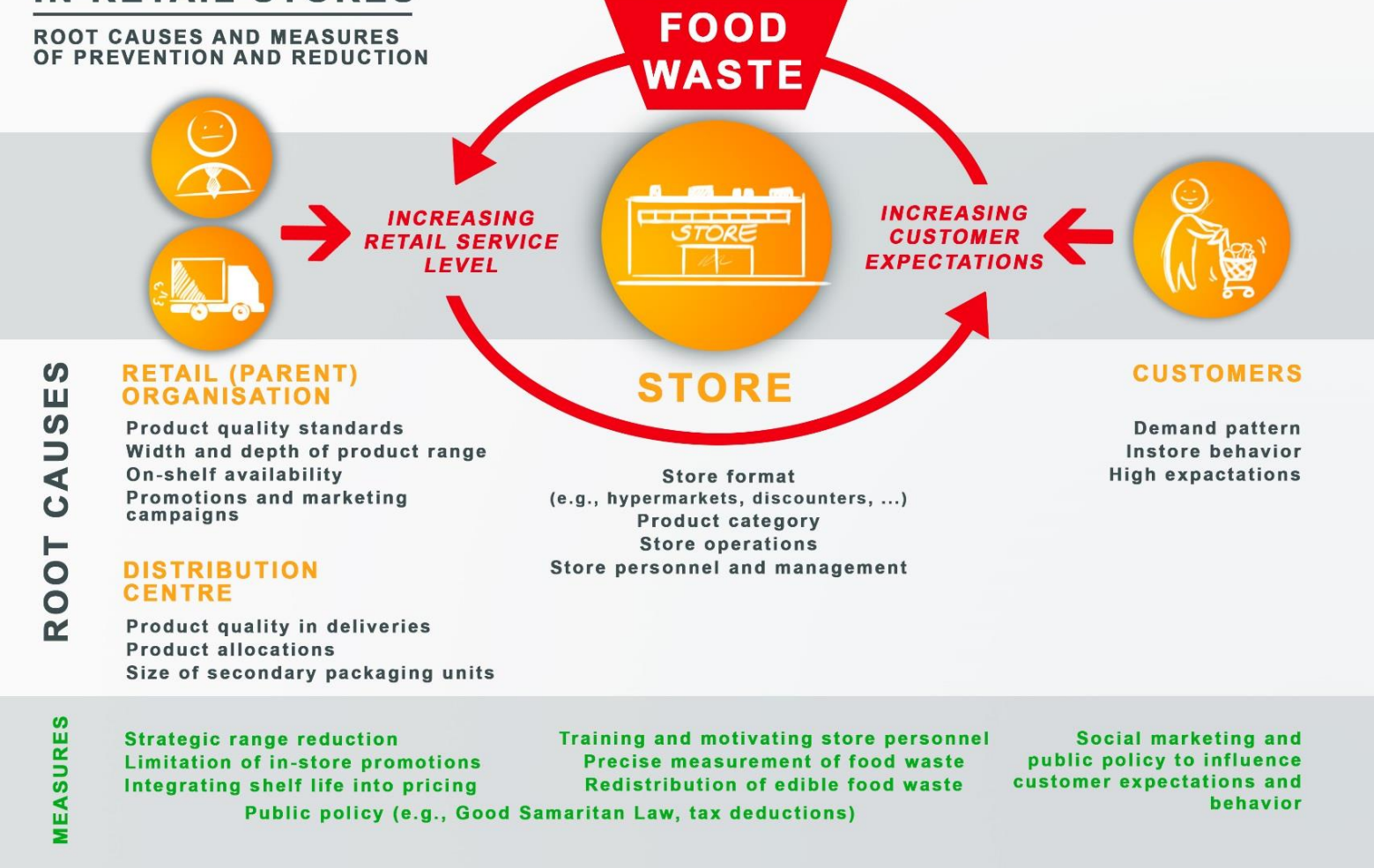

\section{Highlights}

- The paper identifies root causes of food waste across store formats and product categories.

- Case study research, process simulations and expert interviews reveal the following:

○ Demand side: Undesirable in-store customer behaviour and unpredictability of demand.

- Supply side: Inefficient store operations and elevated product requirements.

- Root causes differ across store format and product category characteristics.

- Bigger formats are more heavily affected.

Please cite as: Teller, Christoph, Holweg, Christina, Reiner, Gerald, Kotzab, Herbert. 2018. Retail Store Operations and Food Waste. Journal of Cleaner Production. 


\title{
Retail store operations and food waste
}

\begin{abstract}
This paper focuses on the issue of food waste from a retail and store operations perspective, with the aim to identify the root causes of food waste occurrence at a retail store level across different store formats and product categories. To achieve this, we first conducted case studies, including semi-structured interviews with store managers. This exploratory research involved 28 cases across dominant retail store formats (i.e., super- and hypermarkets and discount and convenience stores). The results along with secondary data research underlie a process simulation modeling approach that quantifies the impact of selected root causes of food waste by considering the dependencies between them. Finally, we conduct semi-structured interviews with 12 food waste experts to confirm findings of the case studies and simulations and to delineate the practical implications of our research and the related solutions. Our findings show that the root causes of food waste are related to undesirable customer behavior and erratic demand, inefficient store operations and replenishment policies, and elevated product (quality) requirements of both retail organizations and customers. Root causes and their impacts differ across store formats and product categories. Furthermore, the interdependencies between the root causes in the different spheres of responsibility and influence (i.e., customers, the store, and the parent organization) are evident. The paper contributes to the literature by providing detailed understanding of retail operations related to the occurrence of food waste across store formats at a product-category level and revealing pathways for preventing and reducing the occurrence of food waste at a retail store level.
\end{abstract}

Keywords: Store operations, Process simulation, Case study research, Food waste, Operationsmarketing interface 


\section{Introduction}

Grocery retailers are facing immense challenges varying from smart shopping, to home delivery innovation, to sustainability in terms of transparency in their food chains on the one hand and the reduction of food waste in their operations on the other hand (Askew, 2018). For example, one difficulty is encouraging customers to buy so-called ugly produce (i.e., slightly flawed groceries), so these products do not end up as waste (Skrovan, 2018). The economic, social and environmental benefits of food waste strategies for US retail store operations represent a potential of nearly US\$20 billion (Perroni, 2018).

Overall, retail store operations have a significant impact on costs, profits, and the service provision of retailers and are key success factors in the grocery industry (Reiner et al., 2013). Surprisingly, scant research has examined the retail store level of operations within the food supply chain (Aschemann-Witzel et al., 2017). Instead, extant research commonly focuses on the elimination of suboptimal outcomes of retail processes in terms of insufficient on-shelf availability (Pal and Byrom, 2003). Here, the underlying assumption is that improved grocery retail and store operations lead to higher on-shelf availability and, thus, a reduced number of out-of-stock situations for customers, which ultimately contributes to improved profitability at the store and retail organization levels. In this paper, we take a different perspective by assessing food waste occurrence from the perspective of retail and store operations. In other words, we focus on the negative outcomes of retail and store operations in terms of too much stock in stores instead of too little.

The term "food waste" used throughout this paper follows the definition of the FAO $(2014,4)$ as "the removal of food from the supply chain which is fit for consumption, or which has spoiled or expired, mainly caused by economic behavior, poor stock management or neglect." In addition to this widely used definition, the FAO addresses the issue of "food loss," which occurs "in the production and distribution segments of the food supply chain and is 
mainly caused by the functioning of the food production and supply system or its institutional and legal framework" (FAO, 2014, 4). Food loss can thus be viewed as an unintended and inevitable consequence of supply chain operations, even though products declared as food waste could be fit for consumption if better managed throughout the supply chain and particularly at a retail store level.

In the retail industry, food waste refers to unsalable products that need to be discarded or recycled. Thus, food waste at the retail stage represents a significant commercial issue given the low overall margins on food products and increasingly high operating costs, particularly at the store level. Another issue for grocery retailers is that a large proportion of the products discarded are still fit for consumption. This ethical dimension of food waste puts increasing pressure on retailers to show corporate social responsibility in terms of the environment and communities and, thus, to reduce as well as recover food waste (Aiello et al., 2014; Gruber et al., 2016).

Despite the commercial and ethical relevance of food waste at the retail stage, the literature has made few attempts to explain either the impact or the interdependencies of the root causes behind its occurrence at the store level. The work considering food waste is largely of a descriptive nature and focuses on the quantification of waste relative to other supply chain stages or discusses the wider implications of food waste occurrence (e.g., Papargyropoulou et al., 2014).

We identify an ethically, environmentally, and commercially relevant research gap in the understanding of the relationships between the antecedents, which we term "root causes," and food waste occurrence at the store level. This gap also entails considering the complexity of food waste occurrence at the retail stage in terms of store formats, product categories, and the interdependencies between store operations and the root causes of food waste. 
To provide a better understanding of and thereby contribute to resolving the issue of food waste, this research aims (1) to identify and explore the root causes of food waste occurrence at the retail store level and (2) to evaluate their impact on waste quantities across different store formats. As such, our focus and, thus, the unit of analysis are the different retail store formats. The theoretical contribution of this paper is to provide an in-depth understanding of retail and store operations related to the occurrence of food waste across store formats at the product-category level. The practical contribution is to reveal pathways through which to prevent and reduce the occurrence of food waste at the retail store level and beyond.

\section{Literature review}

We reviewed the literature on the phenomenon of food waste in general and within the contexts of retailing and retail and store operations. The Appendix presents the identified key studies in the food waste domain in chronological order and compares them across several aspects. From this comparison, we derive the subsequent set of research gaps that our research addresses.

\subsection{Retail-related food waste literature}

A wealth of studies focus on understanding and describing the phenomenon in general and providing an overview on initiatives at a national or international level (European Commission, 2010; Gustavsson et al., 2011; Stenmarck et al., 2011; Buzby and Hyman, 2012; Katajajuuri et al., 2014). Key conclusions are that food waste represents a significant issue affecting all stages of the supply chain, including the retail stage. Various studies are conceptual in nature and portray the complexity of the food waste issue and the interdependencies across food supply chain stages and their stakeholders, including the relevance of information sharing (Papargyropoulou et al., 2014, Kaipia et al., 2013). Other studies on re-distribution strategies (e.g., charities) illustrate the large potential for human 
consumption of unsalable food (Alexander and Smaje, 2008; Aiello et al., 2014; Holweg et al., 2016; Teller et al., 2017). Still other studies examine the further resource potential of food waste by exploring various re-use and recycling techniques and measures (Mirabella et al., 2014; Vandermeersch et al., 2014; Cicatiello et al., 2016; Brancoli et al., 2017).

When comparing research across the supply chain stages, we observe a strong emphasis on the household level and on consumer decision making (Bekin et al., 2006; Parfitt et al., 2010; Koivupuro et al., 2012; Block et al., 2016; Aschemann-Witzel et al., 2017; Aschemann-Witzel, 2018). This literature critically discusses the responsibility of the food distributors and their marketing practices in stores.

Overall, we can conclude that the food waste-related literature reflects an emphasis on describing the magnitude of food waste and its impact in selected geographic settings and across different stages of the food supply chain (see Appendix). The retail stage finds explicit consideration in several key studies (e.g., Eriksson et al., 2012; Lebersorger and Schneider, 2014), which primarily investigate the quantitative dimension of food loss through volume measurement at the store level. These studies, however, do not include the reasons for food waste at the retail level, thus lacking both the operational dimension of a retail store and the instore behaviors of customers.

Research has largely addressed the root causes of food waste occurrence in stores at an aggregated level, without covering the operational reality of retailers or frontline staff, in particular, at the point of sales. To our knowledge, none of the evaluated studies on root causes investigate the phenomenon of food waste in a store environment; rather, they take a distant view of, for example, managers higher up in the organization hierarchy or industry experts or glean insight through secondary data. Moreover, scant work takes into account the different retail contexts of food waste occurrence, even though in-store processes and customer behaviors differ significantly between product categories (e.g., packaged vs. loose produce) 
and store format (e.g., small convenience stores vs. large hypermarkets) (Kotzab and Teller, 2005; Teller et al., 2017). As such, the literature inadequately covers the crucial role of retail and store operations and the interdependencies between the root causes of food waste occurrence. Last, literature fails to explain the split of responsibilities of food waste occurrence across the different stakeholder groups in a retail context (i.e., customers, retail and store management, suppliers, retail marketers, and operations managers). This is crucial because the knowledge of who is responsible is closely related to the establishment and effectiveness of measures to resolve the food waste issue.

\subsection{Food waste-relevant retail and store operations literature}

Research in the fields of retailing, operations management, retail operations, and instore logistics strongly focuses on shelf availability and the prevention of out-of-stock situations, rather than the occurrence of waste in stores (Corsten and Gruen, 2003; Trautrims et al., 2009). Fewer studies address replenishment processes and the efficiency of retail (store) operations processes (Raman et al., 2001; Reiner et al., 2013). In all cases, maintaining the customer service level in terms of availability is paramount, with the cost of over-stocking and wastage only marginally considered. The latter factors are implicitly considered in studies on "shrinkage," or the loss of merchandise due to theft, fraud, administrative errors, damage, or wastage (Howell and Proudlove, 2007; Rekik and Sahin, 2012). Despite the crucial importance of shrinkage at the store level and its widespread use as a key performance indicator in retailing, food waste has been widely neglected in the retail operations management literature. Only recently has logistics literature explored the challenges but also opportunities related to products identified as being unsalable in stores (e.g., in terms of redistributing them to charities or social supermarkets) (Holweg et al., 2016; Teller et al., 2017). Overall, a review of the retail

and store operations literature shows that it mainly features research into logistics and marketing processes related to making products available, with the ultimate goal of selling 
them, while mostly neglecting the reasons products become unsalable, how that affects retail and store operations, and how wastage can be reduced and ultimately prevented.

\subsection{Research gaps}

From our literature review, we identify four research gaps: (1) in-depth understanding of retail and store operations related to food waste occurrence in the supply chain; (2) identification of the root causes of food waste across store formats, considering differences in product categories; (3) interdependencies between the root causes of food waste on a retail stage and beyond; and (4) appreciation of the areas of responsibilities between key stakeholder groups of retail stores related to the root causes of food waste. Our research taps into these gaps and, in contrast with previous studies, takes a holistic view of retail and store operations - with respect to both marketing and logistics - and its management by considering the area of conflict between maximizing on-shelf availability and sales and minimizing food waste.

\section{Methodologies}

Given the paucity of research in the area of food waste at a retail store level, we followed a sequenced, multi-method approach by combining qualitative and quantitative research methodologies. Fig. 1 shows how the three methodologies used build on and complement one another.

\section{Figure 1 about here}

In the first part, we followed an exploratory research design to gain in-depth insights into the phenomenon of food waste occurrence and its root causes at both the product category and the store format level. The aim was to gain a better understanding of the complexities involved in the occurrence and management of food waste and to develop a conceptual model that guided the second part of the study. Consequently, the results of analyzing the qualitative case study data, the derived conceptual model, and secondary data—collected through the case 
study and taken from previous research — fed into the process simulations, whose aim was to quantify and further investigate selected root causes of food waste by considering the dependencies between them. The aggregated findings of the first two parts of the study provide multifaceted insights into the root causes of food waste occurrence related to different store formats and categories. In the third part, we presented our results to experts through semistructured interviews on various areas in the field of food waste and discussed possible measures for tackling the issue at the store and other closely related levels. The goal of this final study was to delineate the practical implications of our research and the related solutions.

\subsection{Exploratory case studies}

The unit of analysis of this first part of the study is the store format - that is, a store configuration characterized by a typical combination of store resources and capabilities, such as location, space (size), number of categories (width of product range), number of stockkeeping units (SKUs) in each category (depth of product range), quality and pricing of products, and service level (Reutterer and Teller, 2009). To account for differences between formats in terms of typical store resources and operational processes behind food waste occurrence, we also investigated multiple cases per format, applying an embedded case study design (Yin, 2011). Consequently, we selected the most common store formatshypermarkets, supermarkets, discount stores, and convenience stores. Within each format, we drew a purposive judgment sample and selected the stores represented by informants who had the expertise to offer insights into food waste occurrence. Our sample consisted of 28 stores from 5 organizations, divided into convenience stores (4 stores/2 organizations), discount stores $(5 / 2)$, supermarkets $(11 / 3)$, and hypermarkets $(8 / 2)$. The different number of stores reflects the frequency of the format in retail markets. Table 1 provides an overview of structural characteristics of the store formats. 
Table 1 about here

Storage facilities across all store formats are similar, consisting of cooling zones and misted areas; an exception is discount stores, which do not provide cooling facilities and therefore must sell all fresh produce by the end of the day. All stores investigated were operated by international and transcontinental retail chains and franchise organizations and were located in a typical Western European retail environment characterized by high market concentration, (price) competition level, and store density. To investigate each case, we applied a qualitative research design with semi-structured interviews. Qualitative methods are well suited to generating in-depth insights into store operations (in-store replenishment and ordering, recycling, and disposal) that lead to particular outcomes (food waste occurrence).

In a first step, we evaluated each case using secondary research to explore the background of the investigated phenomenon in terms of relevant contextual factors, such as distribution channel, store format, store size, turnover, width and depth of product range, and location. These data mainly came from the respective parent retail organization of the stores.

In a second step, we identified core informants on the topic of food waste. After attaining official approval from the top management of each retail chain, we contacted the store managers of the respective stores directly. Our interviewees had remarkably long histories of experience in the retail industry (mean average: 15 years; standard deviation: 11 years) and as managers of the stores investigated (average: 6 years; standard deviation: 9 years).

We conducted in-depth interviews in a third step. A semi-structured interview guide, as outlined in Fig. 2, helped organize the interview stimuli (mostly questions and statements) and stimulate responses and explanations. The interviewers also encouraged the interviewees to convey their professional and personal views and to specify issues related to food waste occurrence at both the store level and the retail stage in general. The interview guide focused 
on major food waste product categories, root causes, and related in-store processes, as well as the issue of edible food waste and its possible distribution to, for example, charities.

Figure 2 about here

On average, the interviews lasted 43 minutes, and observations of food waste on the premises took an average of 15 additional minutes, concluding the investigation. Alongside the interviews and store visits, we collected secondary data to put the qualitative data into a richer context.

The qualitative analysis was based on 20 hours of interviews, which resulted in 410 single-spaced A4 pages of transcript. We analyzed each case, including its description and the differentiation between product categories. Content analysis was applied to the textual data. This analysis approach helped us classify the textual material, reducing it to more relevant, manageable details. We applied a directed content-analysis approach using the different stages of the replenishment and disposal/recycling process as a preliminary coding scheme (Krippendorff, 2004). We amended the scheme and extended it from the discussions as part of the coding process. To handle the large amount of textual data, we used the computer-assisted qualitative data analysis software QSR NVivo 10. Following Saldana (2009), we ensured intercoder reliability in terms of stability, reproducibility, and accuracy related to the coding process by double-coding all interviews in two coding rounds. The results of each coding round were compared and discussed by all researchers with respect to any differences that had occurred. As part of the analysis, we compared the text between stores of the same format, as well as between the different formats, to identify the drivers related to the resources that were typical of different formats and specific to different stores. 


\subsection{Process simulation and model specification}

In this second part of the study, we developed a process simulation model to analyze food waste-related in-store processes. We used a discrete-event simulation tool (www.processmodel.com) to carry out this analysis based on the qualitative case study data, the derived conceptual model, and secondary data (see Fig 1.). The main objective of the simulation model is to investigate important root causes in detail and to provide further insights into different store formats and product categories by considering the empirical data collected from the case study research. Two model limitations, stemming from the case study findings, must be taken into account. First, given experts' insights into the sales patterns of each store format (minimum, maximum, and mode for selected product categories), we assume triangulardistributed demand during the periods of analysis $(\mathrm{T})$. The parameters differ for weekdays and weekends. Second, we treat the supply process as perfect (i.e., the given lead time to be fulfilled and the related delivery time volatility are always 0 ). In other words, we assume that products are delivered from central warehouses without any delivery problems.

To better understand the impacts of different dimensions on the occurrence of food waste revealed in the semi-structured interviews with store managers, we modeled the dynamic dependencies and stochastic characteristics in our conceptual framework using three sources of empirical data from the first part of the study for the operationalization. First, we used primary data derived from the interviews with store managers, which allowed us to specify the dimensions of the model for the retail formats with reference to the identified spheres of responsibility and influence. We also collected quantitative data at the end of each interview, characterizing each store by, for example, characteristics of customer demand and product shelf life. Second, we collected additional data in another round of primary field research mainly for the purpose of the follow-up process simulations. We contacted our store managers by telephone after the store visits took place to obtain key characteristic items for the product 
categories of fruits/vegetables and dairy products, the order quantities with minimum/mode/maximum daily volumes divided into weekdays and weekends, and shelf life. Third, we approached four managers of central distribution centers that supply each of the four store formats and collected secondary data on average storage days and processes of distribution to stores.

To account for the complexity of these dependencies and in accordance with van der Vorst et al. (2009), we applied process simulations to consider dynamic dependencies and stochastic characteristics (Reiner et al., 2013). We explain the model specification based on the conceptual model, as well as the considered empirical data and the relevant variables, in more detail in Section 4.

\subsection{Semi-structured interviews with food waste experts}

To evaluate and complement our findings from the first two parts of the study from the standpoint of practical implications, we conducted semi-structured interviews with 12 food waste experts. Again, we followed a purposive judgment sampling approach and selected interviewees with expert knowledge on food waste occurrence at the retail stage. At the store level, we selected four senior store managers from our sample of 28 cases in the first part of the study, each representing a different format. At the (parent) retail organization and distribution center level, we chose three senior regional managers (responsible for more than 100 stores each) and two senior managers at the headquarters level of two leading grocery retail chains who are also responsible for corporate social responsibility (each chain operates more than 1,000 stores). Last, we chose three senior advisers on public policy matters, including food waste-related matters, who cover the consumer and legislation levels. We interviewed all study participants using an interview guideline that consisted of three parts: first, we briefly presented the main findings with respect to the key drivers of food waste in the four store formats and in different product categories. Second, we asked all interviewees to state possible measures 
related to food waste prevention and reduction across the three spheres of responsibility and influence as identified in our exploratory case studies - that is, the store level, the retail (parent) organization and distribution center level, and the consumer level (including legislation). Third, each measure was critically evaluated on its effectiveness in preventing and/or reducing food waste and its feasibility (e.g., in terms of waste reduction potential, time, and costs).

All interviews were conducted within two weeks by two interviewers; seven were conducted face-to-face and six by telephone. The interviews lasted 45 minutes on average, which resulted in 160 single-spaced A4 pages of transcript. The data analysis followed the same methodological characteristics as in our exploratory case studies and thus comprised a content analysis of our text data. We developed the coding scheme around the various measures the interviewees mentioned with respect to the three spheres of responsibility and influence and their effectiveness and feasibility. The data were double-coded in two coding rounds by the interviewers in the same way as in the methodology of the case studies. Given the significant amount of data, we again used the software QSR NVivo 10.

\section{Results and discussion}

\subsection{Exploratory case studies}

The results of the first part of the study involve the root causes of food waste occurrence in retail store, while we differentiate them between different formats and product categories. Ultimately the main findings feed into the development of a conceptual model that guides the process simulations in the second part of the study.

\subsubsection{List and ranking of root causes}

Food waste at the store level occurs for a variety of reasons. The generated list of 11 root causes extends the indicative lists from the European Commission (2010), Mena et al. (2014), and Lebersorger and Schneider (2014). Table 2 outlines the ranking of these root causes. The ranks (see encircled numbers) reflect a mean value across all ranks provided by 
the interviewees displayed for all store formats and per specific store format. The most highly ranked root cause across formats is related to customers, specifically the limited predictability of their demand and their undesirable behavior when selecting and handling products in store (e.g., damaging products, choosing "newest" products with a latest expiration date). The second-ranked root cause is related to store personnel and subsumes suboptimal behaviors (e.g., poor execution, lack of experience, insufficient leadership by management). The third-ranked cause is products delivered too close to the expiration date by the parent company. Interviews also indicated that the root causes can be interrelated-for example, customers' undesirable behavior and their lack of tolerance of the appearance and quality of products (the sixth-ranked root cause).

Table 2 about here

The identified root causes with their respective spheres of responsibility clearly show the importance of applying a broader perspective to the issue of food waste to account for the interdependencies among the stores, the organizational units upstream and the parent organization, and the households and consumers downstream in the food supply chain (Parfitt et al., 2010). Overall, root causes are related to traditional challenges in grocery retailing, such as (1) properly matching highly fluctuating demand with supply through accurate forecasting, ordering, and replenishment; (2) trading with fast-turning, perishable products in sensitive packaging; and (3) selling to customers who are increasingly demanding in terms of quality and services. Nevertheless, most reasons for the poor execution of retail operations in stores and, thus, the occurrence of food waste lie outside the sphere of influence of the stores' management. These root causes include the commitment of management to internal company guidelines on quality and on-shelf availability and strategies related to product range, pricing, and (in-store) promotions. Furthermore, our research reveals the key drivers of food waste 
through rankings, which provide a distinctive view of the root causes and, unlike other findings in the literature, enable the identification of key issues and, thus, prioritization when targeting food waste at the store level.

\subsubsection{Differences between store formats}

This study also reveals differences among different store formats in terms of the root causes of food waste. In particular, certain format-specific characteristics fuel food waste occurrence, such as store size, footfall, SKU/product range, pricing strategy, and the intensity of promotional activities. For example, in hypermarkets, a main root cause driving food waste is the high-quality standards of the parent organization. In supermarkets, an important root cause is secondary product packaging units, which must be ordered and contain too many products to be sold.

\subsubsection{Differences between product categories}

We also show that, alongside the store format (characteristics), the different logistics and marketing-related characteristics of product categories have a significant impact on food waste occurrence. These characteristics refer to shelf life, product sensitivity, imposed quality standards, and product-specific demand patterns. These in-depth insights into root causes in the respective store format settings feed into the development of our conceptual model and the second and third parts of the study.

\subsubsection{Conceptual model}

This first part is explorative, descriptive, and interpretative in nature and provides limited insights into the complexity of relationships between the root causes and food waste occurrence; it does not account for the interdependencies between the root causes related to different formats and product categories. To overcome these shortcomings, we conceptualize the relationship between root causes and food waste occurrence in different formats by 
applying Slack and Lewis's (2011) strategic reconciliation model and Reiner et al.'s (2013) input/output view of store operations (see Fig. 3). We regard food waste occurrence as a retail operations performance outcome that leads to negative impacts on store performance in terms of costs, reduced profit margins, and lost sales and profits at the product, category, and store levels. Food waste occurrence is positioned between the (decisions on the) utilization of resources and capabilities in terms of operational processes on the supply side of the retail organization and the requirements of the market (represented by performance objectives) on the demand side — namely from the customer.

Figure 3 about here

We thus propose that resources, (operations) processes, and demand for products affect the occurrence of food waste. Accordingly, we assigned the previously identified set of root causes to the dimensions of our conceptual model (see Table 3). For example, the third most frequently stated root cause, products too close to expiry dates when delivered, can be attributed to a higher root cause category of product shelf life and is related to the dimension of resources within our conceptual model. Delivery of products as a root cause clearly falls within the sphere of responsibility of the parent company and the distribution center.

\section{Table 3 about here}

Format-specific store resources refer to tangible and intangible aspects, such as store personnel, product range, personnel experience, and location. Following Reiner et al. (2013), we regard the efficient execution of operational processes as capabilities (e.g., forecasting, ordering, replenishment, merchandising). Following Slack and Lewis (2011), we also emphasize a strong link between resources and a store's main operational processes. The retail operations performance objective that influences operational performance outcomes in terms of food waste entails demand patterns and in-store behavior of customers. Our model is based 
on the findings from exploratory case studies and considers interdependencies among the resources, processes, and demand that affect food waste occurrence. Store resources, processes, and demand, as well as food waste occurrence, differ among store formats, which makes a separate investigation into the relationships outlined necessary. Table 2 and Fig. 3, which depicts our conceptual model, provide the basis for further investigating the root causes of food waste occurrence by means of process simulations.

\subsection{Process simulations}

\subsubsection{Model specifications}

Table 4 summarizes the variables and parameters selected for the process analysis based on the conceptual model. Because of the complexity of the food waste issue at the store level, we focused on the root causes identified through the semi-structured interviews that are the most relevant for retail and store operations management (see Table 2 and Fig. 3).

Table 4 about here

The model comprises different activities related to retail and store operations, mainly those of ordering and replenishment. In terms of processes, additional limitations of our model are that unsatisfied customer demand constitutes lost sales and an ideal in-store logistics process is assumed (i.e., direct delivery to shelf without backroom storage; see Reiner et al., 2013). For the in-store logistics, the retailer uses a standard "order-up-to-level" replenishment policy. With the collected empirical data for customer demand $D$, we run the simulation model to obtain values for the input parameters of safety stock $I s$ and $S$ based on the replenishment lead time $L$ ( 1 day) and period $R$ (1 day). Prior studies have focused on modifications related to extensions of standard inventory policies geared toward improving the performance of perishable products (e.g., constant order policies; Minner and Transchel, 2010). Haijema (2013) reports improvement potentials of between 4 and $25 \%$ of amended inventory policies 
over the standard order-up-to-level policy for perishable products. We address these specific developments in the field of replenishment policies with one related analysis.

$$
\begin{gathered}
S=\bar{X}_{D} \times(L+R)+I s . \\
I s=S F \times S_{D} \times \sqrt{L+R} . \\
D_{t}=\mathrm{T}\left(\min _{D}, \operatorname{mode}_{D}, \max _{D}\right) .
\end{gathered}
$$

We assume that shelf inventory $S I_{t}$ increases by order quantities $Q_{t}$ (arriving in period $t$ ) and decreases by customer demand $D_{t}$ and food waste $F W_{t}$. We define $F W_{t}$ as the shelf inventory with product age $A P S_{t}$ higher than the shelf life $S H L$; each time a product is taken off the shelf, the product age is verified, and should the product age be greater than the accepted shelf life, the product is classified as waste. Finally, $S I_{t}$ is the observed stock position at the end of period $t$.

$$
\begin{gathered}
Q_{t}=\max \left(S-S I_{t}, 0\right) . \\
F W_{t}=\left\{S I_{t-1} \mid A P S_{t}>S H L\right\} . \\
S I_{t}=S I_{t-1}+Q_{t-L}-F W_{t}-\min \left(D_{t}, S I_{t-1}+Q_{t-L}-F W_{t}\right) .
\end{gathered}
$$

We use performance measures to analyze the different store formats and product categories: average food waste $A F W_{T}$ and average fill rate $A F R_{T}$ at the end of the simulation in period T (365 days) with 100 replications.

$$
\begin{gathered}
A F W_{T}=\frac{\sum_{t}^{T} F W_{t}}{\sum_{t}^{T} Q_{t}} . \\
A F R_{T}=1-\frac{\sum_{t}^{T} \max \left(0, D_{t}-\left(S I_{t-1}+Q_{t-L}-F W_{t}\right)\right)}{\sum_{t}^{T} D_{t}} .
\end{gathered}
$$

Table 5 provides an overview of the mean input parameters related to the different store formats for fast-moving products based on the empirical data provided by the interview experts; in particular, the characteristic items of the two core product categories (fruits/vegetables and 
dairy products) most affected by food waste according to our interviewees were loose (not prepackaged) bananas and fresh milk in 1 liter cartons. These two SKUs are highly relevant for all customer groups, are purchased at high frequency, and are of high importance across all store formats. The service levels for each store format were confirmed by the informants of our exploratory case studies. There is one extreme deviation from the standard service-level tactics: for fresh milk, discount stores aim for empty stock at the end of each day.

\section{Table 5 about here}

To investigate the impacts of the various processes and root causes on food waste occurrence, we conducted four analyses (see Table 6). In Analysis I "Shelf Life," we focused on the impact of the merchandising process on the relationship between the characteristics of a product category (i.e., shelf life and demand characteristics) and the occurrence of food waste without in-store capacity constraints for handling SKUs.

Table 6 about here

In Analysis II "Quality Standards," we considered the difference in terms of productdeclared food waste per period because of high internal quality standards $Q S_{i}$ among the different store formats $i$ for fruits (i.e., loose bananas). This analysis is only relevant for loose products because for packed products, the quality can only be verified after opening of the package.

$$
F W_{t}=S I_{t-1} \times Q S_{i}+\left\{\left(S I_{t-1} \times Q S_{i}\right) \mid A P S_{t}>S H L\right\}
$$

In Analysis III "Customer Behavior," we examined customer behavior for packaged products (i.e., 1 liter of fresh milk). We assumed that a certain percentage of customers do not respect the standard first in, first out (FIFO) priority rule and instead select the "newest" product with the latest expiration date (i.e., last in, first out [LIFO]). 
In Analysis IV "Replenishment Policies," we assessed the potential impact of a modified replenishment policy to improve the results presented in Analysis III for packaged products considering consumer behavior (FIFO/LIFO) for hypermarkets and supermarkets. Recent studies have devised extended optimal policies, though these are difficult to implement in practice because of high complexity. Haijema (2013) suggests a simplified heuristic that uses lower and upper bounds for the order quantity (arriving in period t). Thus, we tested the extension (heuristic) of the standard order-up-to-level policy for order quantities $Q_{t}$ for perishable products under consideration of FIFO/LIFO. We illustrate example values for the parameters $\alpha$ and $\beta$ with the available empirical data (see Section 4.1).

$$
Q_{t}=\max \left[\alpha\left(\max \left(S-S I_{t-L-R}, 0\right)\right), \beta D_{t-L-R}\right] .
$$

We used the two performance measures defined previously to carry out the different analyses of the store categories of interest - average fill rate $A F R_{T}$ and average food waste $A F W_{T}$ — which are presented, for each store format and different shelf lives, for the categories of fruits/vegetables and dairy products. Using the input parameters, we calculated the relevant parameters for the replenishment policies: average demand $\bar{X}_{D}$, standard deviation $S_{D}$, and variation coefficient $c v$ (see Table 7). The demand pattern for the two categories differs across store formats and between weekdays and weekends; for example, convenience stores in city areas are frequented by customers from nearby offices, resulting in a higher demand for milk during weekdays.

Table 7 about here

\subsubsection{Simulation outcome}

For Analysis I "Shelf Life," the results presented in Table 8a show that a longer shelf life reduces food waste and increases the service level. Some store formats have more food waste than others. With regard to demand characteristics (illustrated by the coefficient of 
variation $c v$; see Table 7) and target service level, higher demand volatility decreases the "costs" of stationary inventory policies. Furthermore, tactical management decisions (e.g., target service level) have an impact on store performance, particularly with regard to food waste in the discount store. The results for convenience and discount stores are the best. An important finding of Analysis I is that inventory replenishment policies, demand variability, and tactical decisions related to inventory parameters cannot explain exclusively why larger store formats perform better in reality (Lebersorger and Schneider, 2014). We offer four possible explanations for this:

1. In-store logistics (e.g., location/layout, resource capacity) are not considered.

2. Upcycling opportunity in hypermarkets (i.e., the processing of unsalable food products in store to reduce food loss, e.g., fruits into juices) is also not considered. This is not possible in the majority of store types for food safety reasons, which is why we did not model it. Nevertheless, Lebersorger and Schneider (2014) do not provide information about the distribution of empirical food waste. Therefore, it is not possible to judge whether the results they present are significant.

3. Loose products declared food waste because of high internal quality standards are not considered. We analyze this in Analysis II.

4. FIFO is assumed as the standard consumer behavior. We analyze this in Analysis III.

Table 8 a about here

For Analysis II “Quality Standards,” products are disposed of because of high internal quality standards (vs. assumed average quality in retailing or "products being edible"). With different requirements for each store format, these results influence waste performance accordingly. Note that discount stores treat bananas as a destination category and thus apply the same high-quality standards as hypermarkets. The results in Table $8 \mathrm{~b}$ illustrate a different 
situation than that in Analysis I (Table 8a); that is, hypermarkets perform better, while supermarkets and convenience stores do not show any significant differences. Discount stores keep their better performance because of lower-service-level requirements.

With this finding, we cannot reject the proposition that high internal quality standards are the main root cause of food waste of loose products, particularly bananas. Furthermore, this is the main reason hypermarkets perform better than supermarkets and convenience stores.

Table $8 \mathrm{~b}$ about here

For Analysis III "Customer Behavior," the results are based on the assumption that $75 \%$ of customers apply LIFO logic and the remaining percentage apply FIFO logic when picking products from shelves. The results presented in Table $8 \mathrm{c}$ show that there is a significant influence on performance (i.e., food waste). A higher fraction of FIFO consumer behavior related the "best-before-use" date increases food waste.

The main finding here is that store formats that can influence consumer behavior (i.e., reduction of LIFO) perform better. Some analyzed hypermarket cases use special shelf designs to ensure a higher FIFO percentage that contributes to improved performance for packaged products (i.e., 1 liter of fresh milk). The robust performance of discount stores is due to the low service-level objective (i.e., empty stock at the end of each day).

Table $8 \mathrm{c}$ about here

For Analysis IV "Replenishment Policies," Tables 8d and 8e for selected sensitivity analyses present diverse results of the modified replenishment policy. The main findings are that food waste can be reduced with this modified replenishment policy. Nevertheless, the parameters must be optimized for each store format and product characteristic (demand) to provide improved performance results. 
Table $8 \mathrm{~d}$ and $8 \mathrm{e}$ about here

\subsubsection{Summary}

The analysis process provides complementary exploratory insights into the impact of selected root causes of food waste occurrence on the performance of stores. These results reveal that demand patterns and in-store behavior-namely requirements for product quality and consumer behavior (FIFO/LIFO) — in combination with in-store replenishment policies, have a significant influence on quantities of food waste.

Another finding is that pursuing a higher service level does not necessarily deliver better performance in terms of food waste, given the shortcomings of the standard replenishment policies used for in-store logistics. This leads to the proposition that the experience and expertise of store managers and staff are important. The combination of the process flow management of store operations (e.g., reduction of customers' picking the freshest products from the shelf) and "new" replenishment policies provides additional opportunities for improvement.

We found that the application of stationary replenishment policies is due to shelf space constraints and complexity reduction. As such, higher demand volatility decreases the "costs" of stationary inventory policies. However, this needs to be analyzed in more detail by considering technical innovations that enable the implementation of non-stationary inventory policies.

With regard to store format, the highest potential to reduce food waste resides in hypermarkets and supermarkets (see Table 9). Their larger assortments, higher service levels and quality standards, and higher number of personnel tend to increase the probability of food waste occurrence. 
Table 9 about here

\subsection{Semi-structured interviews with food waste experts}

The main contribution of this third part of the study is the identification and derivation of a range of areas for improvement and also three sets of measures for preventing and reducing food waste. Our measures are explicitly targeted at the store and other closely related levels. Nevertheless, we also describe the limitations of each of these measures. One overall finding from all the studies is that a significant reduction of food waste can only be achieved through the joint efforts of store employees, managers, their parent organizations, and customers. Furthermore, we received no objections from the interviewees on the main findings of the first and second parts.

\subsubsection{Measures at the retail store level}

All the experts agreed that measures taken at the store level are highly effective, are less costly and time consuming, and can have an immediate impact. The main reason is that preventing and reducing food waste can be integrated into the existing scope of responsibility of store personnel. The implementation of such measures does not require additional skills and knowledge but rather more attention and consideration by the store and retail management. The clear drawback here is the already-high workload of store personnel in general, the high turnover of staff (up to $80 \%$ on a yearly basis), and the related higher costs of additional human resources required to integrate additional waste prevention and reduction measures into daily work routines. The following three concrete measures were identified by the experts and also evolved from our studies.

Training and motivating store personnel: Retail organizations and stores need to promote increased awareness of and sensitivity to the topic of food waste. This could be 
achieved by training and incorporating the topic in internal guidelines and policies. Food waste reduction could be incentivized through bonuses or even acknowledgments within retail organizations. Overall, the importance of this food waste reduction measure adds to Reiner et al.'s (2013) assertion of the importance of human resources in the efficient execution of instore logistics processes. The downside of this set of measures is the increased cost of training and rewards.

Measurement of food waste: To better manage food waste and thus reward initiatives to reduce waste in stores, it is imperative that its occurrence be recorded more precisely as part of the "umbrella key performance indicator" of shrinkage. This measure clearly requires more effort from store personnel to collect data on actual food waste (e.g., by distinguishing edible and non-edible food waste quantities). Therefore, the benefits derived from managing food waste more effectively must outweigh the additional information cost from collecting such data. Such measures are more difficult to implement in smaller store formats because staff members are less specialized in what they do (e.g., category management, shelf replenishment) and store management also tends to be heavily involved in operational activities.

Redistribution of edible food waste: Given the considerable share of products declared unsalable when still consumable, retailers should be encouraged to facilitate the redistribution of such edible food waste generated in their stores. In line with Teller et al. (2017) the concrete suggestion here is that the retail parent organization should elicit the cooperation of frontline employees to implement processes for making such products available to distribution hubs and charitable organizations (e.g., food banks, social supermarkets) that supply people living in impoverished circumstances. Another suggestion is the implementation of public policy guidelines to encourage passing on food: the Good Samaritan Law, which addresses obstacles related to liability issues, is one option common in several countries. Another option is 
providing financial benefits for retailers donating food by offering tax deductions, a useful measure implemented in France. This measure clearly requires store personnel to carry out additional activities as part of their daily routines. Thus, whether the benefits of redistribution outweigh the costs from the use of additional human resources in the store needs to be critically evaluated. Larger formats, in particular hypermarkets, are better suited for redistribution measures, as the comparable quantities of food waste make it more sensible to implement clearly defined processes.

\subsubsection{Measures at the retail parent organization level}

These measures pertain to a more strategic dimension of reducing food waste at a retail level; however, the experts noted the complexity of implementing them, as well as their sometimes limited feasibility and lack of short-term effectiveness. Nevertheless, if successfully implemented, measures adopted at the retail parent organization level can have a significant and sustainable positive effect on the amount of food waste generated at a retail level. Such suggested measures include the following:

Strategic product range reduction: Our retail experts and the literature both emphasize the benefits for retailers and customers of reducing a product range or the number of SKUs in a category by identifying and focusing on key value items and lines, such as high-equity and high-selling products (e.g., Broniarczyk et al., 1998). If applied as part of a category management strategy, this strategic range reduction can lead to an increase in profits, a decrease in stockouts, a minimization of food waste, and a reduction in the negative effects of choice overload on customers. Nevertheless, providing extensive choice is a competitive advantage of larger store formats over smaller formats. Reducing the range can thus have a negative effect on the competitiveness of retailers operating larger formats. The experts clearly suggested focusing on range reduction in terms of products with high perishability, such as fruits, vegetables, and dairy products. 
Rethinking pricing and promotion strategies: Overall, all our experts criticized the negative effects of price and (in-store) promotions, which are particularly characteristic of hypermarkets and supermarkets. Despite being aware that the widely implemented "high-low" pricing strategy (vs. the "everyday low price" strategy) would need to be re-considered, they perceived the reduction of in-store promotions as a powerful approach to reduce food waste occurrence at both the store and the distribution center levels. In addition, the undesirable instore customer behavior of selecting products with the longest expiry date and ignoring the stacking order on the shelf could be avoided by integrating the product life span into the prices of products. By automatically setting prices lower for products with shorter life spans - based on the expiry date-store managers could incentivize customers not only to buy products with a short shelf life but also to actively look for them, thereby reducing food waste in stores. This innovative proposal would make the markdown process and the related merchandising activities simpler for store personnel and transparent for customers.

Such pricing concepts would require substantial changes to electronic point-of-sale systems and careful promotion of such price discrimination measures based on expiry dates. With respect to these measures, the experts critically mentioned the difficulty of procuring consumers' acceptance of such a new way of price reduction, and this would raise ethical concerns about the affordability of freshness for financially disadvantaged customer groups. Nevertheless, Aschemann-Witzel (2018) found positive consumer evaluations of such measures when they were promoted as marketing activities with the aim to reduce food waste.

All these various measures bear costs for the retail organization. To compensate, communicating about the measures used to reduce and avoid food waste through corporate social responsibility campaigns would have a positive effect on the organization's reputation and image from customers' perspectives, a crucial asset in the food distribution sector. 
Moreover, the additional operational costs related to food waste prevention and reduction could, to some degree, be offset by the benefits of a corporate social responsibility image.

\subsubsection{Measures at the consumer level}

Our experts widely agreed on the importance of including the consumer side when trying to prevent and reduce food waste at the store level. Nevertheless, they also regarded this as the most challenging factor because consumption and shopping habits only change gradually and over time. Thus, significant resources would need to be invested to initiate a change in attitude and behavior in the long run. The experts mentioned the following measure to support the reduction of food waste at the store level:

Influencing customers' expectations and perceptions: Customers' expectations of the immaculacy of fresh produce and the permanent freshness of unpacked bakery products across stores' opening hours could be sensibly managed using social marketing techniques. Effective media for conveying food waste-related messages could include stickers on products and shelves, as well as posters in stores. Thus, customers could be made aware of their responsibility for and contribution to food waste generation. These marketing activities could also be communicated through a neutral third party (e.g., a charity). An example of a public policy measure successfully implemented in the UK is the national campaign "Love Food Hate Waste" (WRAP, 2017). Schools are another important contact point for public policy measures to stimulate early change in the way consumers consider and value food in general.

Overall, the combined findings of all three parts of the study complement and extend the descriptive findings from prior literature on food waste occurrence at a retail level (e.g., Stenmarck et al., 2011; Mena et al., 2014). We conclude that food waste prevention and reduction measures are the most efficient and effective at the retail store level but are shortterm in nature. Nevertheless, they mainly fight the symptoms rather than the systemic problem of food waste occurrence in the retail supply chain. Measures at the parent organization level 
have a more strategic impact, have longer lead times, and are more complex to implement because they require a change in how retailers operate, in terms of product range, promotion, and pricing. Of similar long-term nature and complexity are measures geared toward changing long-established consumer perceptions and shopping behavior.

\section{Conclusions}

Fig. 4 depicts the findings from all three parts of the study. These findings address the identified research gaps, including understanding of food waste occurrence within the context of retail and store operations, identification of root causes and their interdependencies at a store format level and beyond, and an appreciation of different areas of responsibilities in an effort to prevent and/or reduce food waste at the retail and store levels. Overall, we conclude that all different areas within a retail organization - marketing, store, and retail operations and other stages in the food supply chain (e.g., suppliers, households)-should work together to minimize the externalities of food waste occurrence. Next, we present three key conclusions of our research.

Figure 4 about here

\subsection{Interdependence between retail store operations and in-store consumer behavior}

As this research shows, food waste occurrence at the retail store level is based on the interplay between internal (i.e., resources and operations processes of a retailer and store) and external (i.e., demand patterns and in-store consumer behavior) factors. Furthermore, this research reveals key root causes and provides insights into retail store operations that deal with a surplus rather than a deficit situation (food waste vs. stockouts).

We also show the interdependencies between increasing customer expectations and enhancing retailers' standards for product quality and retail services, particularly on-shelf availability and product choice. Such a spiraling tendency in expectations and service provision, as an outcome of the intense competition in the grocery retail industry, leads to a 
large number of the root causes identified through our studies (i.e., high internal product quality standards, high customer quality expectations, permanent on-shelf availability, and frequent in-store promotions). Consequently, we conclude that food waste represents an important issue for retail store operations and marketing processes generated by undesirable customer behavior and high expectations, both nurtured by retailers' increased service provisions.

\subsection{Linking store-format and product-category characteristics with food waste occurrence}

Our study provides insights into the differences between root causes across different store formats. In particular, we show that food waste affects larger formats that offer more choice (wider and deeper product ranges) to a stronger extent than smaller formats. The process simulations investigate the problem in detail and show that the combined issue of demand variability and high service-level targets, particularly in hypermarkets, negatively affects food waste.

The categories containing a high share of products with limited shelf life, sensitive logistical characteristics, and slow or erratic demand patterns (i.e., fruits/vegetables, dairy, and bakery products) are the most severely affected, and they fulfill highly important roles in stores' product ranges, such as "cash-flow contributors," "profit generators," and "retail/store brand reinforcers." Therefore, high product quality and permanent on-shelf availability are paramount for retailers, and food waste has become a necessary and accepted evil.

\subsection{Suboptimal operations at the decoupling point of the grocery supply chain}

A retail store represents the order-decoupling point of a grocery supply chain; it is the place where consumer demand meets retailer supply in terms of product quality and quantities. The inability to satisfy demand through merchandising and replenishment processes is manifested not only in terms of a lack of on-shelf availability but also in terms of food waste. This clearly extends the current scope of retail and store operations literature that exclusively focuses on investigating the out-of-stock issue. The interviews with store managers emphasize 
that the poor execution of store operations, in both in-store replenishment and ordering, is the second most important root cause. In particular, our empirical studies show that the problematic link between elevated product requirements and replenishment processes leads to more food waste. These findings specific to the store level across formats provide further insights into extant and more descriptive research and clearly emphasize the crucial role of the store as a waste generator. We confirm the direct and indirect importance of human resources in the execution of in-store logistics processes in all three parts of our study and conclude that the experience and commitment of stores' management and staff have a significant impact on food waste occurrence and are arguably critical to its prevention.

\section{Future research agenda}

As with all empirical research, the limitations to our study may stimulate further research. This paper focuses on the root causes of food waste occurrence but neglects store processes after the products are declared unsalable and thus designated as waste, as well as the quantitative dimension of food waste (e.g., detailed shrinkage rates, weight of food waste). An emerging field of research involves inventory replenishment policies for perishable goods, whose main focus should be on policies suitable for practical implementation.

To keep our process simulation model as parsimonious as possible, we were not able to include every root cause and retail and store operations process. In a next step, the model could be amended to enable comprehensive joint analyses and an investigation of the dependencies among low on-shelf availability, product range, demand volatility, innovative inventory replenishment policies, and modified customer behavior in influencing food waste occurrence.

The emphasis of this research was on the retail sector and store-based retail formats. Future studies could investigate other non-store-based formats that are becoming increasing important, such as home delivery and click-and-collect, as part of the online retail distribution and other sectors of the food supply chain that are still under-investigated (e.g., the 
manufacturing sector, the service and hospitality sector). Research could also evaluate the food waste issue in (fast-food) restaurants, cafeterias, and other dominant food-catering formats.

\section{References}

Aiello, G., Enea, M., \& Muriana, C. (2014). Economic benefits from food recovery at the retail stage: An application to italian food chains. Waste Management, 34 (7), 1306-1316.

Alexander, C., \& Smaje, C. (2008). Surplus retail food redistribution: An analysis of a third sector model. Resources, Conservation \& Recycling, 52 (11), 1290-1298.

Aschemann-Witzel, J. (2018). Consumer perception and preference for suboptimal food under the emerging practice of expiration date based pricing in supermarkets. Food Quality and Preference, 63 (Supplement C), 119-128.

Aschemann-Witzel, J., de Hooge, I. E., Rohm, H., Normann, A., Bossle, M. B., Grønhøj, A., \& Oostindjer, M. (2017). Key characteristics and success factors of supply chain initiatives tackling consumer-related food waste - A multiple case study. Journal of Cleaner Production, 155, Part 2, 33-45.

Askew, K. (2018). What trends will shape grocery retail in 2018? FoodNavigator, Available at https://www.foodnavigator.com/Article/2017/12/18/What-trends-will-shape-grocery-retail-in-2018 (accessed February 18 2018)

Bekin, C., Carrigan, M., \& Szmigin, I. (2006). Empowerment, waste and new consumption communities. International Journal of Sociology and Social Policy, 26 (1), 32-47.

Block, L. G., Keller, P. A., Vallen, B., Williamson, S., Birau, M. M., Grinstein, A., Haws, K. L., LaBarge, M. C., Lamberton, C., Moore, E. S., Moscato, E. M., Reczek, R. W., \& Tangari, A. H. (2016). The squander sequence: Understanding food waste at each stage of the consumer decision-making process. Journal of Public Policy \& Marketing, 35 (2), 292-304.

Brancoli, P., Rousta, K., \& Bolton, K. (2017). Life cycle assessment of supermarket food waste. Resources, Conservation and Recycling, 118, 39-46.

Broniarczyk, S. M., Hoyer, W. D., \& McAlister, L. (1998). Consumers' perceptions of the assortment offered in a grocery category: The impact of item reduction. Journal of Marketing Research, 35 (2), 166-176.

Buzby, J. C., \& Hyman, J. (2012). Total and per capita value of food loss in the united states. Food Policy, 37 (5), 561-570.

Cicatiello, C., Franco, S., Pancino, B., \& Blasi, E. (2016). The value of food waste: An exploratory study on retailing. Journal of Retailing and Consumer Services, 30, 96-104.

Corsten, D., \& Gruen, T. (2003). Desperately seeking shelf availability: An examination of the extent, the causes, and the efforts to address retail out-of-stocks. International Journal of Retail \& Distribution Management, 31 (12), 605-617.

Eriksson, M., Strid, I., \& Hansson, P. (2012). Food losses in six swedish retail stores: Wastage of fruit and vegetables in relation to quantities delivered. Resources, Conservation and Recycling, 68, 14-20. 
European Commission. (2010). Preparatory study on Food waste across EU 27 (final report). Paris: European Commission in association with AEA Energy, Umwelt Bundesamt and Environment and BIO Intelligence Service.

FAO. (2014). Definitional framework of food loss. Rome: Food and Agriculture of the United Nations.

Gruber, V., Holweg, C., \& Teller, C. (2016). What a waste! exploring the human reality of food waste from the store manager's perspective. Journal of Public Policy \& Marketing, 35 (1), 3-25.

Gustavsson, J., Cederberg, C., Sonesson, U., van Otterdijk, R., \& Meybeck, A. (2011). Global food losses and food waste: Extent, causes and prevention. Rome: Food and Agriculture Organization.

Haijema, R. (2013). A new class of stock-level dependent ordering policies for perishables with a short maximum shelf life. International Journal of Production Economics, 143 (2), 434-439.

Holweg, C., Teller, C., \& Kotzab, H. (2016). Unsaleable grocery products, their residual value and instore logistics. International Journal of Physical Distribution and Logistics Management, 46 (6), 634-658.

Howell, S. D., \& Proudlove, N. C. (2007). A statistical investigation of inventory shrinkage in a large retail chain. International Review of Retail, Distribution \& Consumer Research, 17 (2), 101-120.

Kaipia, R., Dukovska-Popovska, I., \& Loikkanen, L. (2013). Creating sustainable fresh food supply chains through waste reduction. International Journal of Physical Distribution \& Logistics Management, 43 (3), 262-276.

Katajajuuri, J., Silvennoinen, K., Hartikainen, H., Heikkilä, L., \& Reinikainen, A. (2014). Food waste in the finnish food chain. Journal of Cleaner Production, 73, 322-329.

Koivupuro, H., Hartikainen, H., Silvennoinen, K., Katajajuuri, J., Heikintalo, N., Reinikainen, A., \& Jalkanen, L. (2012). Influence of socio-demographical, behavioural and attitudinal factors on the amount of avoidable food waste generated in finnish households. International Journal of Consumer Studies, 36 (2), 183-191.

Kotzab, H., \& Teller, C. (2005). Development and empirical test of a grocery retail instore logistics model. British Food Journal, 107 (8), 594-605.

Krippendorff, K. H. (2004). Content analysis: An introduction to its methodology. Thousand Oaks, CA: Sage.

Lebersorger, S., \& Schneider, F. (2014). Food loss rates at the food retail, influencing factors and reasons as a basis for waste prevention measures. Waste Management, 34 (11), 1911-1919.

Mena, C., Terry, L. A., Williams, A., \& Ellram, L. (2014). Causes of waste across multi-tier supply networks: Cases in the UK food sector. International Journal of Production Economics, 152, 144-158.

Minner, S., \& Transchel, S. (2010). Periodic review inventory-control for perishable products under servicelevel constraints. OR Spectrum, 32 (4), 979-996.

Mirabella, N., Castellani, V., \& Sala, S. (2014). Current options for the valorization of food manufacturing waste: A review. Journal of Cleaner Production, 65, 28-41.

Pal, J. W., \& Byrom, J. W. (2003). The five ss of retail operations: A model and tool for improvement. International Journal of Retail and Distribution Management, 31 (10), 518-528.

Papargyropoulou, E., Lozano, R., K. Steinberger, J., Wright, N., \& Ujang, Z. b. (2014). The food waste hierarchy as a framework for the management of food surplus and food waste. Journal of Cleaner Production, 76 (0), 106-115. 
Parfitt, J., Barthel, M., \& Macnaughton, S. (2010). Food waste within food supply chains: Quantification and potential for change to 2050. Philosophical Transactions of the Royal Society B: Biological Sciences, 365 (1554), 3065-3081.

Perroni, E. (2018). New guide helps retailers implement food wast solutions. Food Tank, Available at https://foodtank.com/news/2018/02/refed-retail-food-waste-guide-solutions/ (accessed February 18 2018)

Raman, A., DeHoratius, N., \& Ton, Z. (2001). Execution: The missing link in retail operations. California Management Review, 43 (3), 136-152.

Reiner, G., Teller, C., \& Kotzab, H. (2013). Analyzing the efficient execution of in-store logistics processes in grocery retailing? the case of dairy products. Production and Operations Management, 22 (4), 924-939.

Rekik, Y., \& Sahin, E. (2012). Exploring inventory systems sensitive to shrinkage - analysis of a periodic review inventory under a service level constraint. International Journal of Production Research, 50 (13), 3529-3546.

Reutterer, T., \& Teller, C. (2009). Store format choice and shopping trip types. International Journal of Retail \& Distribution Management, 37 (8), 695-710.

Saldana, J. (2009). The coding manual for qualitative researchers. Los Angeles: Sage.

Skrovan, S. (2018). 'Ugly produce' delivery service comes to chicago. FoodDIVE, Available at https://www.fooddive.com/news/grocery--ugly-produce-delivery-service-comes-to-chicago/512366/ (accessed February 18 2018)

Slack, N., \& Lewis, M. (2011). Operations strategy. Harlow: Financial Times Prentice Hall.

Stenmarck, Å, Hanssen, O. J., \& Werge, M. (2011). Initiatives on prevention of food waste in the retail and wholesale trades. Copenhagen: Nordic Council of Ministers.

Teller, C., Holweg, C., \& Kotzab, H. (2017). Stores, edible food waste, and social redistribution. In A. Lindgreen, M. Hingley, R. Angell, J. Memery \& J. Vanhamme (Eds.), A stakeholder approach to managing food (pp. 311-325). Farnham: Gower Publishing.

Trautrims, A., Grant, D. B., Fernie, J., \& Harrison, T. (2009). Optimizing on-shelf availability for customer service and profit. Journal of Business Logistics, 30 (2), 231-247.

van der Vorst, J., Tromp, S., \& van der Zee, D. (2009). Simulation modelling for food supply chain redesign; integrated decision making on product quality, sustainability and logistics. International Journal of Production Research, 47 (23), 6611-6631.

Vandermeersch, T., Alvarenga, R. A. F., Ragaert, P., \& Dewulf, J. (2014). Environmental sustainability assessment of food waste valorization options. Resources, Conservation and Recycling, 87, 57-64.

WRAP. (2017). Love food hate waste Available at http://www.wrap.org.uk/content/love-food-hate-waste (accessed February 18 2018).

Yin, R. K. (2011). Case study research: Design and methods. London: Sage. 


\section{Figures}

Fig. 1: The relationships between the sequenced and complementary study methodologies.

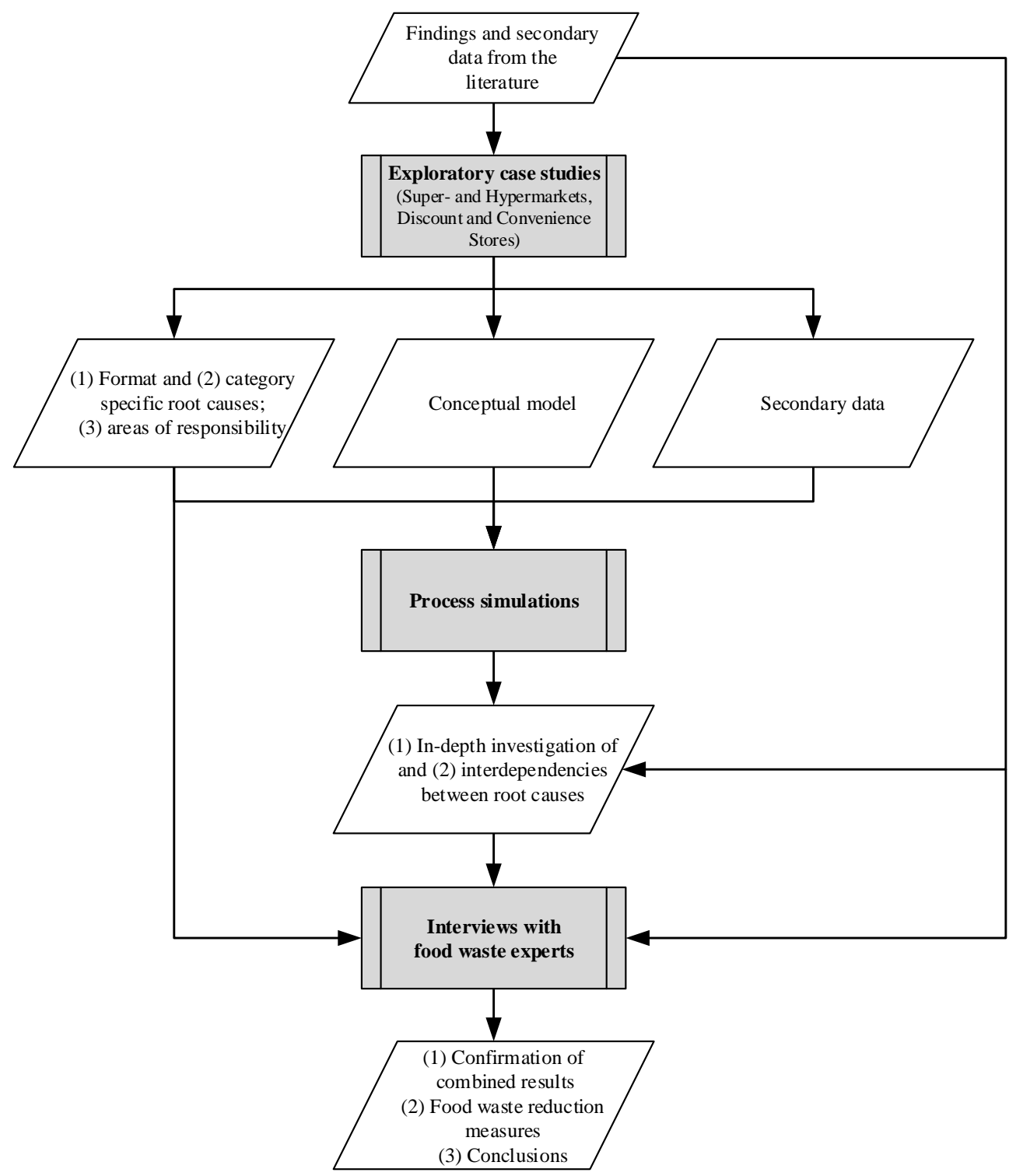

Notes: Rectangles, research processes from data collection to analysis; parallelograms, process in- and outputs; 
Fig. 2. The interview guide used in the exploratory case studies.

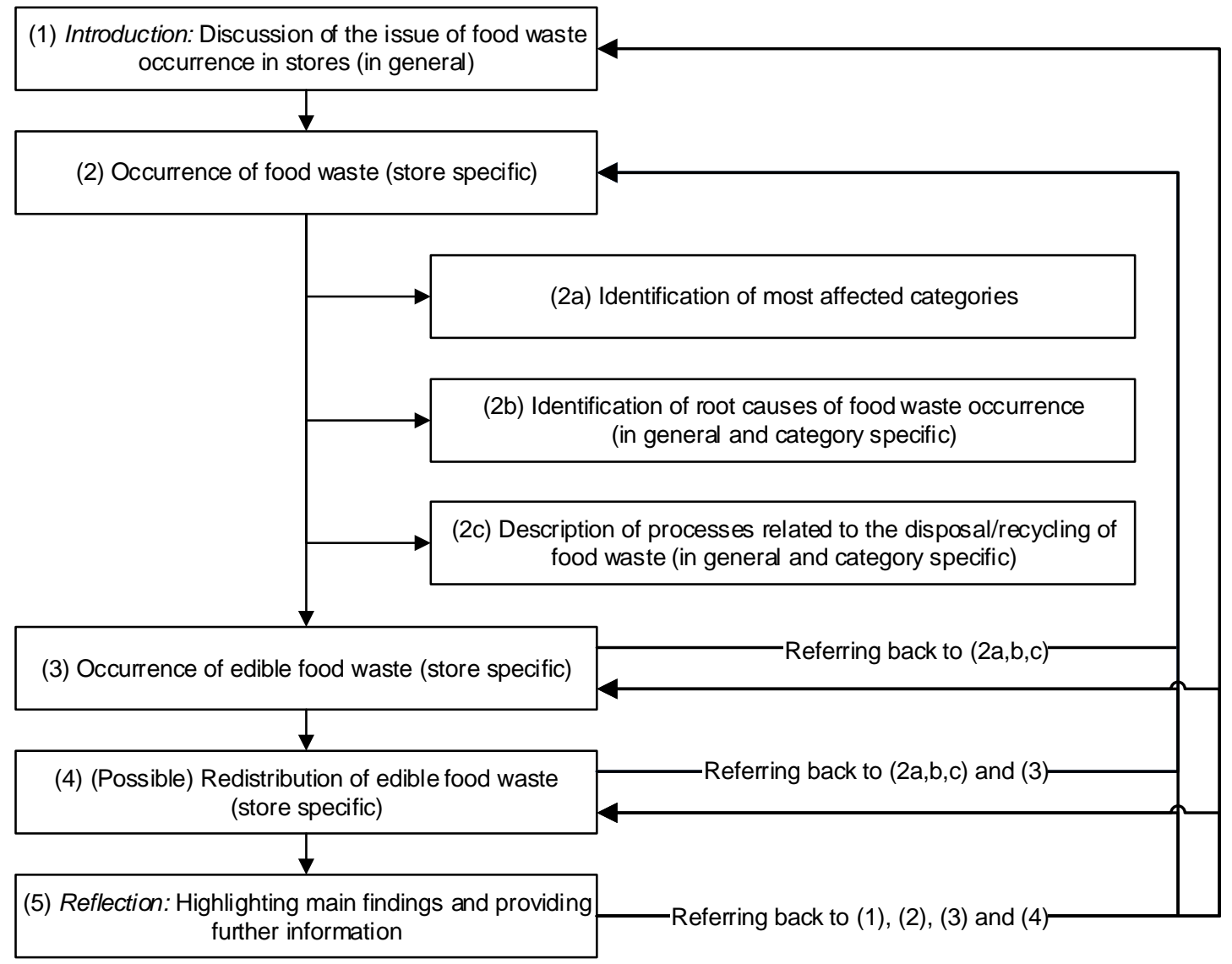


Fig. 3. The conceptual model based on the exploratory case studies that underlies the process simulation

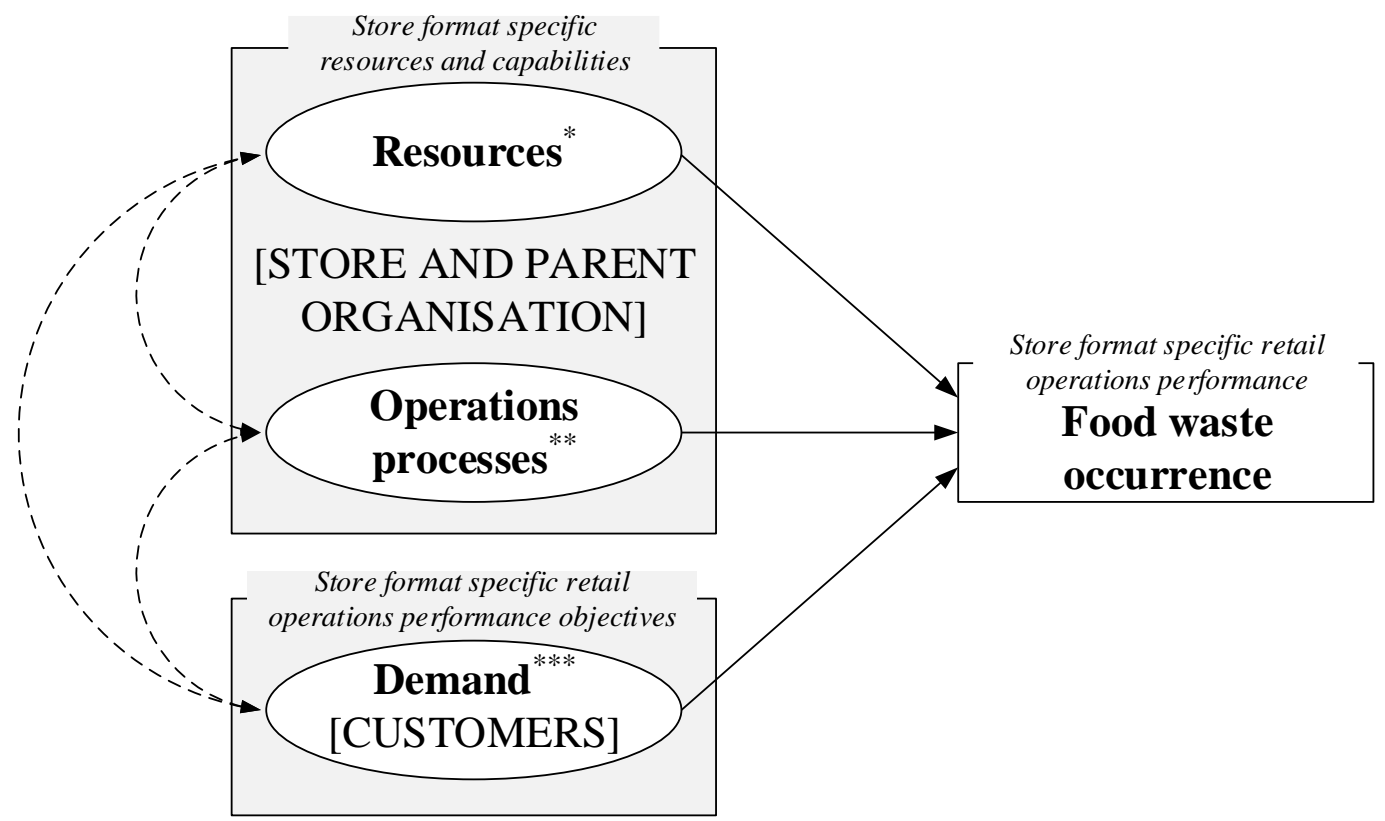

Notes: * refers the root causes: store management and personnel, product shelf life, product quality, product range, packaging size; ** refers the root causes: store management and personnel, store delivery (quality), merchandising, in-store replenishment, marketing/in-store promotion; *** refers the root causes: demand patterns and in-store behaviour, requirements on product quality; see Table 2; dotted double-headed arrows highlight the interdependencies between the root causes. 
Fig. 4. The summary of findings showing the root causes of food waste in retail stores.

\section{FOOD WASTE IN RETAIL STORES ROOT CAUSES AND MEASURES OF PREVENTION AND REDUCTION}

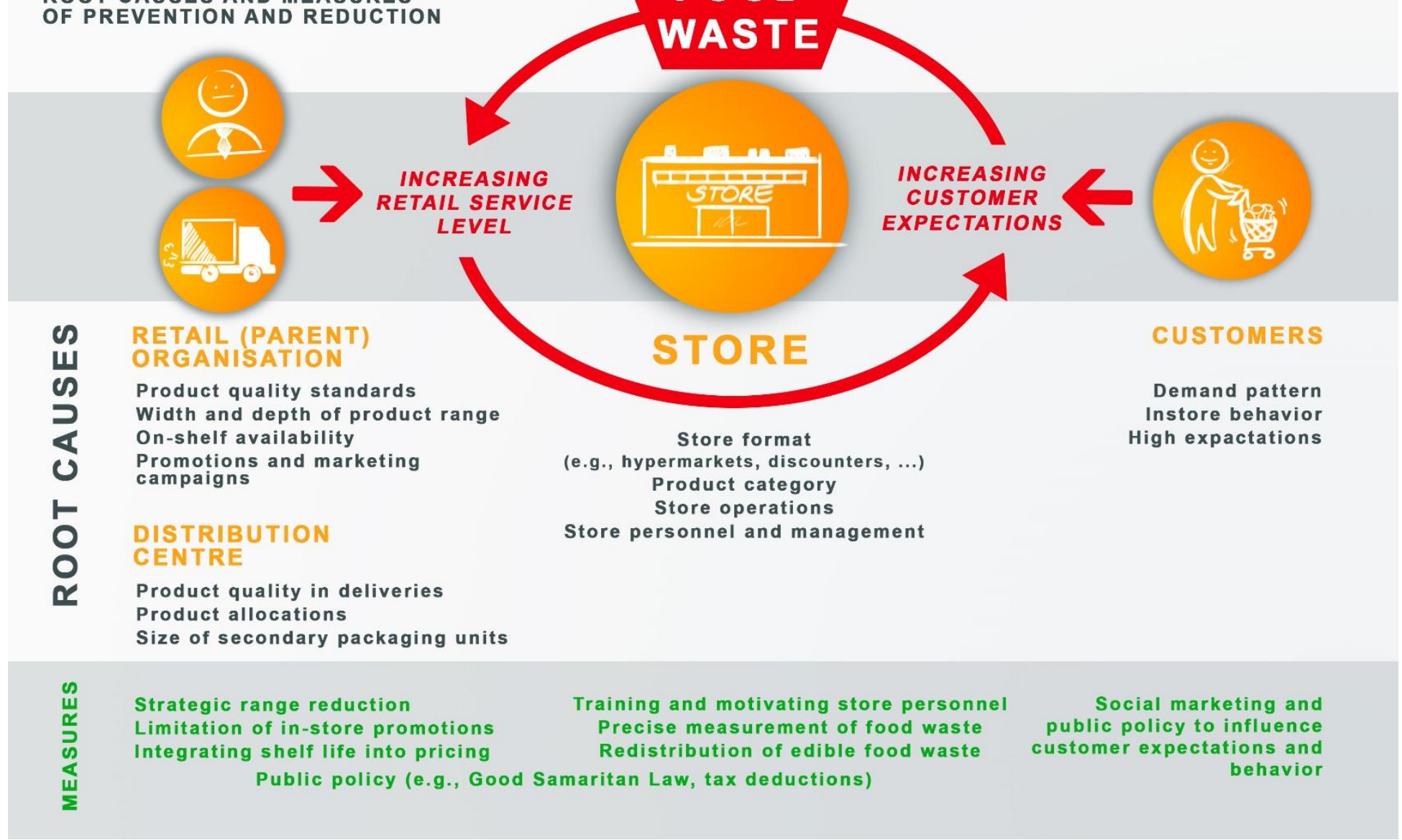


Tables

Table 1

The characterization of store formats under investigation.

\begin{tabular}{|c|c|c|c|c|}
\hline $\begin{array}{l}\text { Format } \\
\text { Characterization }\end{array}$ & Hypermarket & Supermarket & Discount store & Convenience store \\
\hline Floor space (avg. $\mathrm{m}^{2}$ ) & 1,905 & 456 & 646 & 197 \\
\hline $\begin{array}{l}\text { Full-time equivalent } \\
\text { employees (avg.) }\end{array}$ & 52 & 11 & 7 & 14 \\
\hline $\begin{array}{l}\text { Store managers years } \\
\text { of experience (avg.) }\end{array}$ & 8 & 7 & 6 & 15 \\
\hline $\begin{array}{l}\text { Staff turnover } \\
\text { (avg./year) }\end{array}$ & $5 \%-50 \%$ & $0 \%-30 \%$ & $50 \%-80 \%$ & $0 \%-10 \%$ \\
\hline $\begin{array}{l}\text { Customers per day } \\
\text { (avg.) }\end{array}$ & 1,458 & 920 & 1,517 & 145 \\
\hline Number of SKUs (ca.) & 14,000 & 8,000 & 2,000 & 1,400 \\
\hline $\begin{array}{l}\text { Share of promotional } \\
\text { activities }\end{array}$ & High & High & Low & Low \\
\hline Counter services & $\begin{array}{c}\text { Full-range counter } \\
\text { services }\end{array}$ & $\begin{array}{l}\text { Selected food counter } \\
\text { services }\end{array}$ & No counter services & $\begin{array}{c}\text { Selected food counter } \\
\text { services }\end{array}$ \\
\hline \multirow{2}{*}{$\begin{array}{l}\text { Out-of-stock } \\
\text { occurrence }\end{array}$} & Infrequent & Infrequent & Frequent & Varying \\
\hline & minimized & minimized & accepted & minimized \\
\hline
\end{tabular}


Table 2

Store managers' ranking of food waste root causes.

\begin{tabular}{|c|c|c|c|c|c|}
\hline \multirow[b]{2}{*}{ Root causes } & \multirow{2}{*}{$\begin{array}{l}\text { Across } \\
\text { all store } \\
\text { formats }\end{array}$} & \multicolumn{4}{|c|}{ Per store format } \\
\hline & & $\begin{array}{l}\text { Hyper- } \\
\text { market }\end{array}$ & $\begin{array}{l}\text { Super- } \\
\text { market }\end{array}$ & $\begin{array}{l}\text { Discoun } \\
\mathrm{t} \\
\text { store }\end{array}$ & $\begin{array}{l}\text { Conveni } \\
\text {-ence } \\
\text { store }\end{array}$ \\
\hline $\begin{array}{l}\text { Limited predictability of actual customer demand across the range and } \\
\text { undesirable customer behavior when selecting or handling products } \\
\text { Poor execution by personnel (ordering, replenishment), low motivation } \\
\text { insufficient number, lack of experience, insufficient leadership, and } \\
\text { commitment } \\
\text { Products too close to expiry dates when delivered }\end{array}$ & & & & & \\
\hline High-quality standards by the parent organization & & & & & \\
\hline Poor product quality in deliveries of fresh produce to the store & & & & & \\
\hline $\begin{array}{l}\text { Customers' lack of tolerance to the appearance and quality of fresh } \\
\text { produce } \\
\text { Too many products allocated to a store (e.g., during promotions) }\end{array}$ & & & & & \\
\hline $\begin{array}{l}\text { Internal company requirements to facilitate } 100 \% \text { on-shelf availability } \\
\text { products, problems related to forecasting and replenishment } \\
\text { Width (number of product categories) and depth (choice within } \\
\text { categories) of range } \\
\text { Secondary packaging units too large }\end{array}$ & (0) & & & & \\
\hline $\begin{array}{l}\text { Higher product allocations during promotional periods and creation of } \\
\text { fluctuating demand through marketing and visual merchandising }\end{array}$ & 1 & & & & \\
\hline
\end{tabular}

\section{Notes: The encircled numbers are based on mean values and}

cases, root causes had the same importance when the results were ave the aggregated ranking of the root causes by store managers; in some 
Table 3

The assignment of food waste root causes to dimensions of the conceptual model.

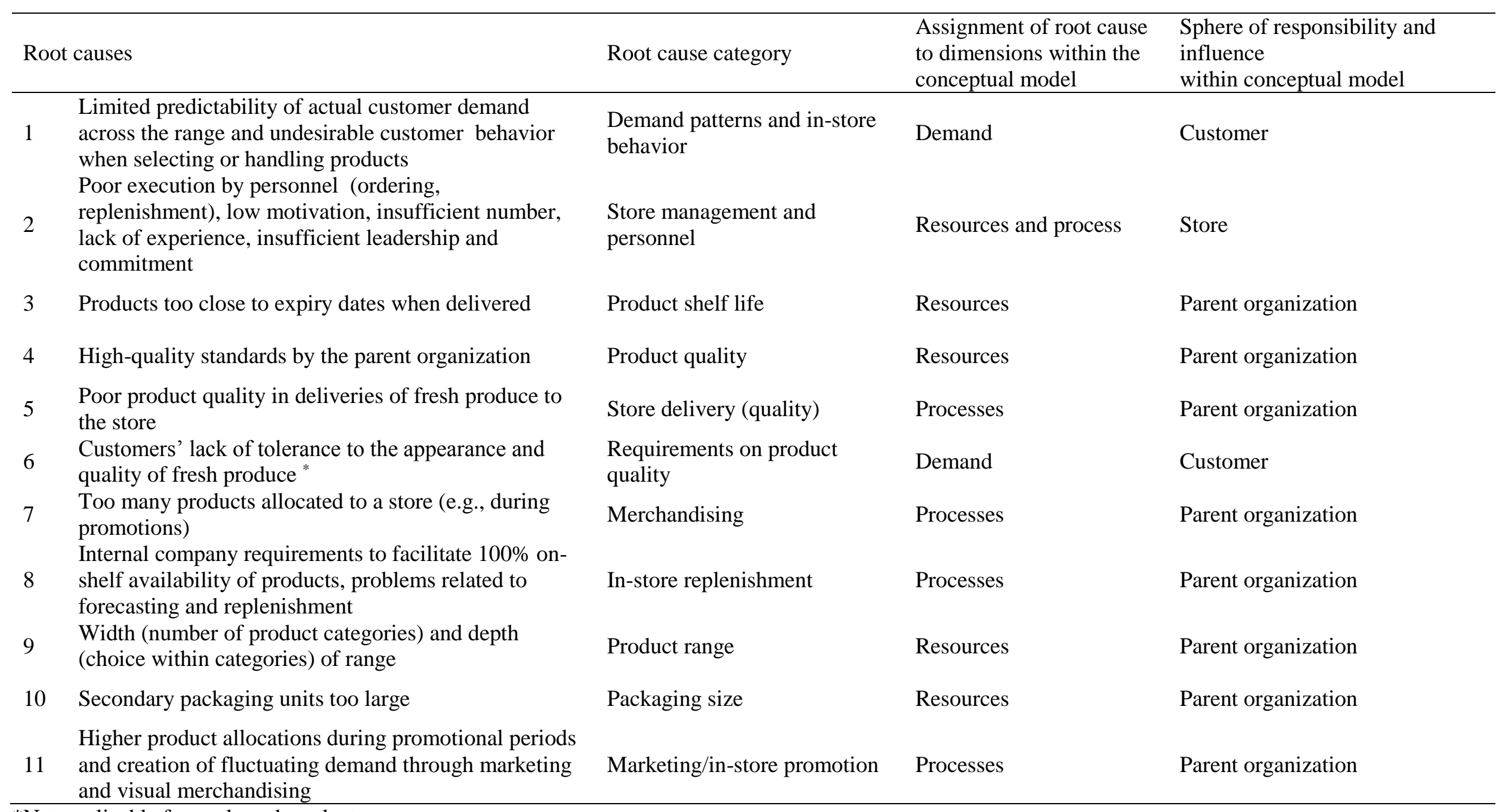

*Not applicable for packaged products. 
Table 4

Variables and input parameters of the simulation model.

\begin{tabular}{ll}
\hline Variable/parameter & Description \\
\hline$F I F O$ & Shelf management - percentage of FIFO \\
$L I F O$ & Shelf management - percentage of LIFO \\
$L$ & Replenishment lead time (days) \\
$S H L$ & Shelf life (days) \\
$Q_{t}$ & Order quantity delivered L period later (units) \\
$S$ & Base stock level (units) \\
CSL & Cycle service level \\
$S F$ & Safety factor \\
$D_{t}$ & Average purchase transactions per weekday and per weekend day (units) \\
$A P S_{t}$ & Age of product in stock (days) \\
$R$ & Review period (time between successive orders) \\
$S I_{t}$ & Stock position (units) \\
$Q S$ & Product declared food waste because of high internal quality standards \\
$A F W_{T}$ & (percentage of stock that is sorted out each period) \\
$A F R_{T}$ & Average food waste per category and store type (as percentage) \\
\hline
\end{tabular}


Table 5

The input parameters of the process simulations related to the two key product categories.

\begin{tabular}{|c|c|c|c|c|}
\hline \multicolumn{5}{|c|}{ Fruits \& vegetables (bananas-kg) } \\
\hline \multirow{2}{*}{$\begin{array}{l}\text { Variable/ } \\
\text { parameter }\end{array}$} & \multicolumn{4}{|c|}{ Format $(i)$} \\
\hline & Hypermarket & Supermarket & Discount store & Convenience store \\
\hline $\min _{D}{ }^{*}$ & $70 / 110$ & $41 / 62$ & $162 / 162$ & $10 / 14$ \\
\hline $\operatorname{mode}_{D}{ }^{*}$ & $100 / 160$ & $51 / 88$ & $216 / 216$ & $30 / 25$ \\
\hline $\max _{D}{ }^{*}$ & $180 / 250$ & $76 / 93$ & $270 / 270$ & $35 / 46$ \\
\hline$C S L / S F$ & $98 \% / 2.05$ & $98 \% / 2.05$ & $90 \% / 1.28$ & $98 \% / 2.05$ \\
\hline$Q S$ & $1.5 \%$ & $5.6 \%$ & $1.4 \%$ & $5.8 \%$ \\
\hline \multicolumn{5}{|c|}{ Dairy products (fresh milk 1l) } \\
\hline \multirow{2}{*}{$\begin{array}{l}\text { Variable/ } \\
\text { parameter }\end{array}$} & \multicolumn{4}{|c|}{ Format $(i)$} \\
\hline & Hypermarket & Supermarket & Discount store & Convenience store \\
\hline $\min _{D}{ }^{*}$ & $50 / 100$ & $59 / 122$ & $328 / 328$ & $5 / 8$ \\
\hline $\operatorname{mode}_{D}{ }^{*}$ & $70 / 200$ & $75 / 135$ & $528 / 528$ & $27 / 15$ \\
\hline $\max _{D}{ }^{*}$ & $100 / 200$ & $100 / 146$ & $576 / 576$ & $32 / 23$ \\
\hline$C S L / S F$ & $98 \% / 2.05$ & $98 \% / 2.05$ & $60 \% / 0.25$ & $98 \% / 2.05$ \\
\hline \multicolumn{5}{|c|}{$\begin{array}{l}\text { Notes: Based on secondary data collected through the case study research; }{ }^{*} \text { weekday/weekend } \\
C S L \ldots . . . \text { cycle service level } \\
S F \ldots \ldots . . \text { service factor } \\
Q S . . . . . . . \text { Product declared food waste because of high internal quality standards (percentage of stock } \\
\quad \text { that is sorted out each period) }\end{array}$} \\
\hline
\end{tabular}

Table 6

The variables and parameters of the variations of the simulation model.

\begin{tabular}{lcccccc}
\hline Analysis & Store formats & SHL & Fruits & Dairy & LIFO & Results \\
\hline I & all & $3-4 / 4-5$ & $X$ & $X$ & $0 \%$ & Table 8a \\
II & all & 4 & $X$ & - & $0 \%$ & Table 8b \\
III & all & $4-5$ & - & $X$ & $75 \%$ & Table 8c \\
IV & Super- \& & $4-5$ & - & $X$ & $75 \%$ & Table 8d,e \\
& Hypermarket & & & & & \\
\hline Notes: & & & & & \\
SHL ..... shelf life (days) & & & & \\
LIFO ... shelf management - percentage of LIFO &
\end{tabular}


Table 7

The parameters calculated on the basis of input parameters: weekday/weekend day.

\begin{tabular}{|c|c|c|c|c|}
\hline \multicolumn{5}{|c|}{ Fruits \& vegetables (bananas) } \\
\hline \multirow{2}{*}{$\begin{array}{l}\text { Variable/ } \\
\text { parameter }\end{array}$} & \multicolumn{4}{|c|}{ Format } \\
\hline & Hypermarket & Supermarket & Discount store & Convenience store \\
\hline $\bar{X}_{D}^{*}$ & $117 / 173$ & $56 / 81$ & $216 / 216$ & $25 / 28$ \\
\hline$S_{D}{ }^{*}$ & $23 / 29$ & 7/8 & $22 / 22$ & $5 / 7$ \\
\hline$c v^{*}$ & $0.2 / 0.17$ & $0.13 / 0.09$ & $0.1 / 0.1$ & $0.2 / 0.25$ \\
\hline \multicolumn{5}{|c|}{ Dairy products (milk $1 l)$} \\
\hline \multicolumn{2}{|c|}{ Variable/ } & \multicolumn{2}{|r|}{ Format } & \\
\hline parameter & Hypermarket & Supermarket & Discount store & Convenience store \\
\hline $\bar{X}_{D}^{*}$ & 73/167 & $78 / 131$ & $477 / 477$ & $21 / 15^{*}$ \\
\hline$S_{D}{ }^{*}$ & $10 / 24$ & $8 / 7$ & $54 / 54$ & $6 / 3$ \\
\hline$c v^{*}$ & $0.14 / 0.14$ & $0.10 / 0.05$ & $0.11 / 0.11$ & $0.29 / 0.2$ \\
\hline \multicolumn{5}{|c|}{ Notes: $*$ weekday/weekend } \\
\hline \multicolumn{5}{|c|}{$\begin{array}{l}S_{D} \ldots \ldots . . . \text { demand standard deviation for period } t \\
c v \ldots \ldots \ldots \text { coefficient of variation }\end{array}$} \\
\hline
\end{tabular}


Table 8a

Modeling results of Analysis I (means and standard deviations).

\begin{tabular}{|c|c|c|c|c|}
\hline \multicolumn{5}{|c|}{ Format } \\
\hline Category & \multicolumn{2}{|l|}{ Hypermarket } & \multicolumn{2}{|l|}{ Supermarket } \\
\hline \multicolumn{5}{|c|}{ Fruits/vegetables } \\
\hline SHL & 3 & 4 & 3 & 4 \\
\hline $\mathrm{AFW}_{\mathrm{T}}$ & $8.27 / .01 \%$ & $0.94 / .01 \%$ & $9.02 / .03 \%$ & $1.38 / .01 \%$ \\
\hline $\mathrm{AFR}_{\mathrm{T}}$ & $99.86 / .01 \%$ & $99.62 / .01 \%$ & $99.46 / .05 \%$ & $99.44 / .01 \%$ \\
\hline \multicolumn{5}{|c|}{ Dairy products } \\
\hline SHL & 4 & 5 & 4 & 5 \\
\hline $\mathrm{AFW}_{\mathrm{T}}$ & $12.55 / .01 \%$ & $2.31 / .01 \%$ & $1.46 / .01 \%$ & $1.21 / .01 \%$ \\
\hline \multirow[t]{2}{*}{$\mathrm{AFR}_{\mathrm{T}}$} & $96.17 / .01 \%$ & $99.78 / .01 \%$ & $99.46 / .01 \%$ & $99.71 / .01 \%$ \\
\hline & \multicolumn{2}{|c|}{ Discount store } & \multicolumn{2}{|c|}{ Convenience store } \\
\hline \multicolumn{5}{|c|}{ Fruits/vegetables } \\
\hline SHL & 3 & 4 & 3 & 4 \\
\hline $\mathrm{AFW}_{\mathrm{T}}$ & $1.93 / .01 \%$ & $0.55 / .01 \%$ & $2.73 / .02 \%$ & $0.32 / .01 \%$ \\
\hline $\mathrm{AFR}_{\mathrm{T}}$ & $99.12 / .01 \%$ & $98.91 / .01 \%$ & $99.82 / .02 \%$ & $99.69 / .02 \%$ \\
\hline \multicolumn{5}{|c|}{ Dairy products } \\
\hline SHL & 4 & 5 & 4 & 5 \\
\hline $\mathrm{AFW}_{\mathrm{T}}$ & $0.40 / .01 \%$ & $0.09 / .01 \%$ & $0 / 0 \%$ & $0 / 0 \%$ \\
\hline $\mathrm{AFR}_{\mathrm{T}}$ & $98.69 / .01 \%$ & $99.00 / .01 \%$ & $99.95 / .01 \%$ & $99.95 / .01 \%$ \\
\hline \multicolumn{5}{|c|}{$\begin{array}{l}\text { Notes: } \\
S H L \ldots . . \text { shelf life (days) } \\
A F W_{T} \ldots \text { Average food waste per category and store type (as percentage) } \\
A F R_{T} \ldots . \text { Average fill rate per category and store type (as percentage) }\end{array}$} \\
\hline
\end{tabular}


Table $8 b$

Modeling results of Analysis II (means and standard deviations), assuming a shelf life of four days.

\begin{tabular}{|c|c|c|}
\hline \multicolumn{3}{|c|}{ Format } \\
\hline Category & Hypermarket & Supermarket \\
\hline \multicolumn{3}{|c|}{ Fruits/vegetables } \\
\hline $\mathrm{AFW}_{\mathrm{T}}$ & $2.38 / .05 \%$ & $6.14 / .14 \%$ \\
\hline \multirow[t]{2}{*}{$\mathrm{AFR}_{\mathrm{T}}$} & $99.19 / .04 \%$ & $97.93 / .10 \%$ \\
\hline & Discount store & Convenience store \\
\hline \multicolumn{3}{|c|}{ Fruits/vegetables } \\
\hline $\mathrm{AFW}_{\mathrm{T}}$ & $2.01 / .04 \%$ & $6.15 / .26 \%$ \\
\hline $\mathrm{AFR}_{\mathrm{T}}$ & $98.43 / .03 \%$ & $97.56 / .16 \%$ \\
\hline \multicolumn{3}{|c|}{$\begin{array}{l}\text { Notes: } \\
S H L \ldots . . . \text { shelf life (days) } \\
A F W_{T} \ldots \text { Average food waste per category and store type (as percentage) } \\
A F R_{T} \ldots . \text { Average fill rate per category and store type (as percentage) }\end{array}$} \\
\hline
\end{tabular}


Table 8c

Modeling results of Analysis III (means and standard deviations), assuming that $75 \%$ of products is replenished on a LIFO principle.

\begin{tabular}{|c|c|c|c|c|}
\hline \multicolumn{5}{|c|}{ Format } \\
\hline Category & \multicolumn{2}{|l|}{ Hypermarket } & \multicolumn{2}{|l|}{ Supermarket } \\
\hline \multicolumn{5}{|c|}{ Dairy products } \\
\hline SHL & 4 & 5 & 4 & 5 \\
\hline $\mathrm{AFW}_{\mathrm{T}}$ & $21.53 / .18 \%$ & $11.87 / .12 \%$ & $12.53 / .15 \%$ & $8.20 / .16 \%$ \\
\hline $\mathrm{AFR}_{\mathrm{T}}$ & $86.16 / .18 \%$ & $90.01 / .12 \%$ & $91.74 / .30 \%$ & $92.90 / .36 \%$ \\
\hline & \multicolumn{2}{|l|}{ Discount store } & \multicolumn{2}{|c|}{ Convenience store } \\
\hline \multicolumn{5}{|c|}{ Dairy products } \\
\hline SHL & 4 & 5 & 4 & 5 \\
\hline $\mathrm{AFW}_{\mathrm{T}}$ & $0.59 / .01 \%$ & $0.52 / .01 \%$ & $7.41 / .15 \%$ & $3.17 / .19 \%$ \\
\hline $\mathrm{AFR}_{\mathrm{T}}$ & $98.51 / .05 \%$ & $98.58 / .03 \%$ & $94.33 / .18 \%$ & $97.81 / .21 \%$ \\
\hline \multicolumn{5}{|c|}{$\begin{array}{l}\text { Notes: } \\
S H L \ldots . . \text { shelf life (days) } \\
A F W_{T} . . \text { Average food waste per category and store type (as percentage) } \\
A F R_{T} . . \text { Average fill rate per category and store type (as percentage) }\end{array}$} \\
\hline
\end{tabular}


Table 8d

Modeling results of Analysis IV for dairy products (means and standard deviations), assuming that $75 \%$ of products are replenished on a LIFO principle, have a four-day shelf life, and modified replenishment policy with parameters $\alpha$ and $\beta$.

\begin{tabular}{|c|c|c|c|c|}
\hline & \multicolumn{2}{|c|}{$75 \%$ LIFO $/ \alpha=0.9 / \beta=0.5$} & \multicolumn{2}{|c|}{$75 \%$ LIFO $/ \alpha=0.9 / \beta=0.4$} \\
\hline & Hypermarket & Supermarket & Hypermarket & Supermarket \\
\hline $\mathrm{AFW}_{\mathrm{T}}$ & 19.38/.19\% & $11.81 / .12 \%$ & $19.36 / .18 \%$ & $11.85 / .14 \%$ \\
\hline \multirow[t]{3}{*}{$\mathrm{AFR}_{\mathrm{T}}$} & $85.90 / .18 \%$ & $89.41 / .36 \%$ & $85.90 / .18 \%$ & $89.26 / .35 \%$ \\
\hline & \multicolumn{2}{|c|}{$75 \%$ LIFO $/ \alpha=0.8 / \beta=0.5$} & \multicolumn{2}{|c|}{$75 \%$ LIFO $/ \alpha=0.8 / \beta=0.4$} \\
\hline & Hypermarket & Supermarket & Hypermarket & Supermarket \\
\hline $\mathrm{AFW}_{\mathrm{T}}$ & $17.24 / .17 \%$ & $10.63 / .12 \%$ & $17.20 / .19 \%$ & $10.64 / .13 \%$ \\
\hline $\mathrm{AFR}_{\mathrm{T}}$ & $84.95 / .16 \%$ & $90.30 / .32 \%$ & $84.96 / .17 \%$ & $90.27 / .34 \%$ \\
\hline $\begin{array}{l}\text { Notes: } \\
\text { SHL..... } \\
A F W_{T . .} \\
A F R_{T . . .}\end{array}$ & $\begin{array}{l}\text { ife (days) } \\
\text { ge food waste pe } \\
\text { ge fill rate per ca }\end{array}$ & $\begin{array}{l}\text { ategory and sto } \\
\text { gory and store } t\end{array}$ & $\begin{array}{l}\text { (as percentage) } \\
\text { percentage) }\end{array}$ & \\
\hline
\end{tabular}


Table 8e

Modeling results Analysis IV for dairy products (means and standard deviations), assuming that $75 \%$ of products are replenished on a LIFO principle, have a five-day shelf life, and modified replenishment policy with parameters $\alpha$ and $\beta$.

\begin{tabular}{|c|c|c|c|c|}
\hline & \multicolumn{2}{|c|}{$75 \%$ LIFO $/ \alpha=0.9 / \beta=0.5$} & \multicolumn{2}{|c|}{$75 \%$ LIFO $/ \alpha=0.9 / \beta=0.4$} \\
\hline & Hypermarket & Supermarket & Hypermarket & Supermarket \\
\hline $\mathrm{AFW}_{\mathrm{T}}$ & $10.94 / .12 \%$ & $7.56 / .15 \%$ & $10.87 / .14 \%$ & $7.52 / .16 \%$ \\
\hline \multirow[t]{3}{*}{$\mathrm{AFR}_{\mathrm{T}}$} & $89.95 / .23 \%$ & $93.38 / .47 \%$ & $90.11 / .27 \%$ & $93.39 / .39 \%$ \\
\hline & \multicolumn{2}{|c|}{$75 \%$ LIFO $/ \alpha=0.8 / \beta=0.5$} & \multicolumn{2}{|c|}{$75 \%$ LIFO $/ \alpha=0.8 / \beta=0.4$} \\
\hline & Hypermarket & Supermarket & Hypermarket & Supermarket \\
\hline $\mathrm{AFW}_{\mathrm{T}}$ & 9.86/.13\% & $6.76 / .10 \%$ & $9.82 / .15 \%$ & $6.72 / .11 \%$ \\
\hline $\mathrm{AFR}_{\mathrm{T}}$ & $89.70 / .23 \%$ & $93.78 / .36 \%$ & $89.82 / .26 \%$ & $93.81 / .34 \%$ \\
\hline $\begin{array}{l}\text { Notes: } \\
\text { SHL.... } \\
A F W_{T} \text {. } \\
A F R_{T .} .\end{array}$ & $\begin{array}{l}\text { life (days) } \\
\text { ge food waste pe } \\
\text { ge fill rate per ca }\end{array}$ & $\begin{array}{l}\text { ategory and stc } \\
\text { gory and store }\end{array}$ & $\begin{array}{l}\text { (as percentage) } \\
\text { percentage) }\end{array}$ & \\
\hline
\end{tabular}


Table 9

The potential to reduce food waste per store format and root cause.

Improvement potential

\begin{tabular}{lcccc}
\hline \multicolumn{1}{c}{ Format } & Hypermarket & Supermarket & Discount store & Convenience store \\
Root cause & High & High & High & High \\
Merchandising process & High & Medium & Low & Low \\
$\begin{array}{l}\text { Internal quality standards } \\
\begin{array}{l}\text { Customer behaviour } \\
\text { picking newest products) }\end{array}\end{array}$ & High & High & Medium & Medium \\
$\begin{array}{l}\text { Modified replenishment } \\
\text { process }\end{array}$ & High & High & High & High \\
\hline
\end{tabular}




\section{Appendix}

A comparison of retail related food waste literature.

\begin{tabular}{|c|c|c|c|c|c|c|c|c|c|c|}
\hline \multirow[b]{2}{*}{ Authors (Year) } & \multirow[b]{2}{*}{ Key Focus } & \multirow[b]{2}{*}{ Methodology } & \multicolumn{8}{|c|}{ Explicit consideration of/diffentiation between } \\
\hline & & & 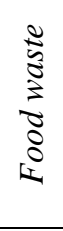 & $\frac{\vec{\pi}}{2}$ & 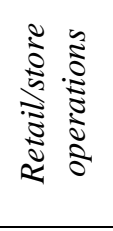 & 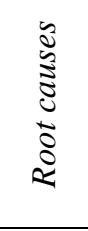 & $\frac{\sqrt[n]{5}}{5}$ & 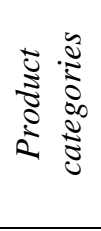 & 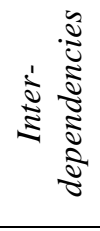 & 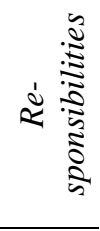 \\
\hline $\begin{array}{l}\text { Alexander and } \\
\text { Smaje (2008) }\end{array}$ & $\begin{array}{l}\text { Analysis of logistical processes of food } \\
\text { waste redistribution between retail } \\
\text { organizations, redistribution } \\
\text { organization, and charities in the UK }\end{array}$ & $\begin{array}{l}\text { Mixed Methods } \\
\text { Case study with } 2 \text { retailers, } 1 \text { redistributor, and } \\
2 \text { charities } \\
\text { - Semi-structured interviews with managers } \\
\text { - In-store observations incl. quantitative data } \\
\text { - Expert interviews with senior retail } \\
\text { managers }\end{array}$ & $\mathrm{Y}$ & $\mathrm{Y}$ & $\mathrm{Y}$ & $\mathrm{N}$ & $\mathrm{N}$ & $\mathrm{N}$ & $\mathrm{N}$ & $\mathrm{N}$ \\
\hline $\begin{array}{l}\text { European } \\
\text { Commission } \\
(2010)\end{array}$ & $\begin{array}{l}\text { First European report on the status of } \\
\text { food waste initiatives across EU } 27 \\
\text { countries }\end{array}$ & $\begin{array}{l}\text { Mixed Method } \\
\text { - Quantitative data from EUROSTAT data } \\
\text { - Qualitative data from expert interviews } \\
\text { across governmental organizations, non- } \\
\text { profit, and private companies }\end{array}$ & $\mathrm{Y}$ & $\begin{array}{c}\mathrm{Y} \\
{[\mathrm{SC}]}\end{array}$ & $\mathrm{N}$ & $\mathrm{N}$ & $\mathrm{N}$ & $\mathrm{N}$ & $\mathrm{N}$ & $\mathrm{N}$ \\
\hline $\begin{array}{l}\text { Gustavsson et al. } \\
(2011)\end{array}$ & $\begin{array}{l}\text { Report on volume of food waste and } \\
\text { food loss along the entire food supply } \\
\text { chain globally and per geographic } \\
\text { regions }\end{array}$ & $\begin{array}{l}\text { Mixed Methods } \\
\text { - Quantitative data from FAO, literature data, } \\
\text { and estimations }\end{array}$ & $\mathrm{Y}$ & $\begin{array}{c}\mathrm{N} \\
{[\mathrm{SC}]}\end{array}$ & $\mathrm{N}$ & $\mathrm{N}$ & $\mathrm{N}$ & $\mathrm{Y}$ & $\mathrm{N}$ & $\mathrm{N}$ \\
\hline $\begin{array}{l}\text { Stenmarck et al. } \\
\text { (2011) }\end{array}$ & $\begin{array}{l}\text { Holistic report on food waste in the retail } \\
\text { and wholesale sector in Northern Europe } \\
\text { focusing on reasons of occurrence, } \\
\text { volume estimates, initiatives, and } \\
\text { proposals for prevention }\end{array}$ & $\begin{array}{l}\text { Single Method } \\
\text { - Expert interviews with representative of } \\
\text { wholesale and retail organizations as well as } \\
\text { trade associations in Sweden, Finland, and } \\
\text { Norway } \\
\text { - } 26 \text { semi structured interviews }\end{array}$ & $\mathrm{Y}$ & $\begin{array}{c}\mathrm{Y} \\
{[\mathrm{W}]}\end{array}$ & $\mathrm{Y}$ & $\mathrm{Y}$ & $\mathrm{N}$ & $\mathrm{Y}$ & $\mathrm{N}$ & $\begin{array}{c}\mathrm{Y} \\
\text { partly }\end{array}$ \\
\hline $\begin{array}{l}\text { Buzby and } \\
\text { Hyman (2012) }\end{array}$ & $\begin{array}{l}\text { Estimation of total and per capita value } \\
\text { of food loss in the United States focusing } \\
\text { on the retail and consumer level }\end{array}$ & $\begin{array}{l}\text { Single Method } \\
\text { - Estimations based on statistical data from } \\
\text { US Department of Agriculture (ERS) }\end{array}$ & $\mathrm{Y}$ & $\mathrm{Y}$ & $\mathrm{N}$ & $\underset{\text { partly }}{\mathrm{Y}}$ & $\mathrm{N}$ & $\mathrm{Y}$ & $\mathrm{N}$ & $\begin{array}{c}\mathrm{Y} \\
\text { partly }\end{array}$ \\
\hline
\end{tabular}




\begin{tabular}{|c|c|c|c|c|c|c|c|c|c|c|}
\hline $\begin{array}{l}\text { Eriksson et al. } \\
(2012)\end{array}$ & $\begin{array}{l}\text { Investigation of recorded and unrecorded } \\
\text { food waste in fruits/vegetables at store } \\
\text { level highlighting the importance of pre- } \\
\text { store waste }\end{array}$ & $\begin{array}{l}\text { Mixed Methods } \\
\text { - Quantitative data from deliveries and sales } \\
\text { from } 6 \text { supermarkets in Sweden } \\
\text { - In-store observations }\end{array}$ & Y & $\mathrm{Y}$ & $\mathrm{Y}$ & $\mathrm{Y}$ & $\begin{array}{c}\mathrm{Y} \\
(\mathrm{SM})\end{array}$ & $\begin{array}{c}\mathrm{Y} \\
\text { partly }\end{array}$ & $\mathrm{N}$ & $\mathrm{N}$ \\
\hline Kaipia (2013) & $\begin{array}{l}\text { Analysis of information sharing and } \\
\text { process management for fresh food in the } \\
\text { retail and wholesale sector } \\
\text { in Northern Europe }\end{array}$ & $\begin{array}{l}\text { Single Method } \\
\text { - Exploratory case study with representative of } \\
3 \text { companies (wholesale and retail } \\
\text { organization; logistics provider) } \\
\text { - Quantitative data on orders, forecasting, } \\
\text { delivery, and sales }\end{array}$ & Y & $\begin{array}{c}\mathrm{Y} \\
{[\mathrm{W}]}\end{array}$ & $\mathrm{Y}$ & $\mathrm{N}$ & $\mathrm{N}$ & $\begin{array}{c}\mathrm{N} \\
\text { partly }\end{array}$ & $\mathrm{N}$ & $\mathrm{N}$ \\
\hline $\begin{array}{l}\text { Aiello et al. } \\
\text { (2014) }\end{array}$ & $\begin{array}{l}\text { Development of a model for optimizing } \\
\text { food recovery between retailers and } \\
\text { redistribution companies }\end{array}$ & $\begin{array}{l}\text { Single Method } \\
\text { Mathematic model using secondary data on cost } \\
\text { and profit from retail organization }\end{array}$ & $\mathrm{Y}$ & $\mathrm{Y}$ & $\mathrm{N}$ & $\mathrm{N}$ & $\mathrm{N}$ & $\mathrm{N}$ & $\mathrm{N}$ & $\mathrm{N}$ \\
\hline $\begin{array}{l}\text { Katajajuuri et al. } \\
(2014)\end{array}$ & $\begin{array}{l}\text { Analysis of food waste occurrence } \\
\text { covering the household level as well as } \\
\text { the service and retail sector in Finland; } \\
\text { estimation on the national volume of } \\
\text { food waste occurrence and its economic } \\
\text { impact }\end{array}$ & $\begin{array}{l}\text { Mixed Methods } \\
\text { Quantitative data from } \\
\text { - Households (diary study, } n=380) \\
\text { - Service companies }(n=3) \\
\text { - Retail associations } \\
\text { Regression analysis }\end{array}$ & $\mathrm{Y}$ & $\begin{array}{c}\mathrm{Y} \\
{[\mathrm{SC}]}\end{array}$ & $\mathrm{N}$ & $\mathrm{N}$ & $\mathrm{N}$ & $\mathrm{Y}$ & $\mathrm{N}$ & $\mathrm{N}$ \\
\hline $\begin{array}{l}\text { Lebersorger and } \\
\text { Schneider (2014) }\end{array}$ & $\begin{array}{l}\text { Quantification of food loss rates in a } \\
\text { retail organization in Austria }\end{array}$ & $\begin{array}{l}\text { Single Method } \\
\text { Quantitative data on national level (EPOS- } \\
\text { scanning data from } 612 \text { outlets) }\end{array}$ & $\mathrm{Y}$ & $\mathrm{Y}$ & $\mathrm{N}$ & $\mathrm{N}$ & $\mathrm{N}$ & $\begin{array}{c}\mathrm{Y} \\
\text { partly }\end{array}$ & $\mathrm{N}$ & $\mathrm{N}$ \\
\hline $\begin{array}{l}\text { Mirabella et al. } \\
\text { (2014) }\end{array}$ & $\begin{array}{l}\text { Analysis of food waste occurring at the } \\
\text { manufacturing stage; potential and } \\
\text { constraints for producing new products } \\
\text { based on reuse and recycling }\end{array}$ & $\begin{array}{l}\text { Single Method } \\
\text { - Literature meta-study based on } 50 \text { scientific } \\
\text { articles }\end{array}$ & $\mathrm{Y}$ & $\underset{[\mathrm{F}, \mathrm{M}]}{\mathrm{N}}$ & $\mathrm{N}$ & $\mathrm{N}$ & $\mathrm{N}$ & $\begin{array}{c}\mathrm{Y} \\
\text { partly }\end{array}$ & $\mathrm{N}$ & $\mathrm{N}$ \\
\hline $\begin{array}{l}\text { Papargyropoulou } \\
\text { et al. (2014) }\end{array}$ & $\begin{array}{l}\text { Development of a framework of best } \\
\text { options for the prevention and } \\
\text { management of food waste across key } \\
\text { stakeholders }\end{array}$ & $\begin{array}{l}\text { Single Method } \\
7 \text { group interviews with } 23 \text { specialists from key } \\
\text { stakeholders (governmental organizations, non- } \\
\text { profit, and private companies) } \\
\text { - Semi-structured interviews }\end{array}$ & $\mathrm{Y}$ & $\begin{array}{c}\mathrm{Y} \\
{[\mathrm{SC}]}\end{array}$ & $\mathrm{N}$ & $\mathrm{N}$ & $\mathrm{N}$ & $\mathrm{N}$ & $\mathrm{N}$ & $\mathrm{N}$ \\
\hline
\end{tabular}




\begin{tabular}{|c|c|c|c|c|c|c|c|c|c|c|}
\hline $\begin{array}{l}\text { Vandermeersch et } \\
\text { al. (2014) }\end{array}$ & $\begin{array}{l}\text { Analysis of environmental performance } \\
\text { of food waste using a two-scenario } \\
\text { approach (anaerobic digestion or animal } \\
\text { feed) }\end{array}$ & $\begin{array}{l}\text { Multiple Methods } \\
\text { - Exploratory case study based on data from a } \\
\text { retailer, a digestion company and a feed } \\
\text { production plant in Belgium } \\
\text { - Quantitative data from interviews and } \\
\text { secondary data (e.g., food waste volume, } \\
\text { energy and electricity consumption, packaging } \\
\text { waste, transportation) } \\
\text { Qualitative observational data from company } \\
\text { visits }\end{array}$ & $\mathrm{Y}$ & $\begin{array}{c}\mathrm{Y} \\
{[\mathrm{R}]}\end{array}$ & $\mathrm{Y}$ & $\mathrm{N}$ & $\mathrm{N}$ & $\underset{\text { partly }}{\mathrm{Y}}$ & $\mathrm{N}$ & $\mathrm{N}$ \\
\hline $\begin{array}{l}\text { Block et al. } \\
\text { (2016) }\end{array}$ & $\begin{array}{l}\text { Investigation of psychological } \\
\text { underpinnings of food waste at consumer } \\
\text { level from acquisition to consumption } \\
\text { and disposal }\end{array}$ & $\begin{array}{l}\text { Single Method } \\
\text { Conceptual article deriving transformative } \\
\text { consumer solutions }\end{array}$ & $\mathrm{Y}$ & $\begin{array}{c}\mathrm{Y} \\
{[\mathrm{C}]}\end{array}$ & $\mathrm{N}$ & $\mathrm{Y}$ & $\mathrm{N}$ & $\mathrm{N}$ & $\mathrm{N}$ & $\mathrm{N}$ \\
\hline $\begin{array}{l}\text { Cicatiello et al. } \\
(2016)\end{array}$ & $\begin{array}{l}\text { Quantification of food waste and } \\
\text { assessment of its environmental, social, } \\
\text { and economic value of food waste at } \\
\text { retail store level }\end{array}$ & $\begin{array}{l}\text { Mixed Methods } \\
\text { - Quantitative data (e.g., delivery, sales, } \\
\text { buying costs) in one Italian supermarket } \\
\text { - In-store observations } \\
\text { - Statistical data on ecological footprint }\end{array}$ & $\mathrm{Y}$ & $\mathrm{Y}$ & $\mathrm{Y}$ & $\mathrm{N}$ & $\begin{array}{c}\mathrm{Y} \\
{[\mathrm{SM}]}\end{array}$ & $\mathrm{Y}$ & $\mathrm{N}$ & $\mathrm{N}$ \\
\hline $\begin{array}{l}\text { Gruber et al. } \\
(2016)\end{array}$ & $\begin{array}{l}\text { Exploration of the human reality of food } \\
\text { waste from the perspective of store } \\
\text { managers and employees }\end{array}$ & $\begin{array}{l}\text { Mixed Methods } \\
\text { - Multiple case study across all store formats } \\
\text { - Semi-structured interviews with store } \\
\text { managers at the premises }(n=32)\end{array}$ & $\mathrm{Y}$ & $\begin{array}{c}\mathrm{Y} \\
{[\mathrm{W}]}\end{array}$ & $\mathrm{N}$ & $\mathrm{N}$ & $\mathrm{Y}$ & $\mathrm{N}$ & $\mathrm{N}$ & $\begin{array}{c}\mathrm{Y} \\
\text { partly }\end{array}$ \\
\hline $\begin{array}{l}\text { Holweg et al. } \\
(2016)\end{array}$ & $\begin{array}{l}\text { Identification of edible food waste in } \\
\text { retail stores per product category and } \\
\text { proposal for redistribution with } \\
\text { economic, ecological, and social benefits }\end{array}$ & $\begin{array}{l}\text { Mixed Methods } \\
\text { - Multiple case study across all retails store } \\
\text { formats } \\
\text { - Semi-structured interviews with store } \\
\text { managers on the premises }(n=32) \\
\end{array}$ & $\mathrm{Y}$ & $\begin{array}{c}\mathrm{Y} \\
{[\mathrm{W}]}\end{array}$ & $\mathrm{Y}$ & $\mathrm{N}$ & $\mathrm{Y}$ & $\mathrm{Y}$ & $\mathrm{N}$ & $\mathrm{N}$ \\
\hline $\begin{array}{l}\text { Aschemann- } \\
\text { Witzel et al. } \\
(2017)\end{array}$ & $\begin{array}{l}\text { Analysis of success factors to reduce } \\
\text { consumer-related food waste across key } \\
\text { stakeholders }\end{array}$ & $\begin{array}{l}\text { Single Method } \\
\text { - Multiple case study with } 26 \text { cases from } \\
\text { capacity-building initiatives, redistribution } \\
\text { organizations, retailers } \\
\text { - Semi-structured interviews with } \\
\text { representatives of each organization }\end{array}$ & $\mathrm{Y}$ & $\begin{array}{c}\mathrm{Y} \\
{[\mathrm{C}]}\end{array}$ & $\mathrm{N}$ & $\mathrm{Y}$ & $\mathrm{N}$ & $\mathrm{N}$ & $\mathrm{N}$ & $\mathrm{N}$ \\
\hline
\end{tabular}




\begin{tabular}{|c|c|c|c|c|c|c|c|c|c|c|}
\hline $\begin{array}{l}\text { Brancoli et al. } \\
(2017)\end{array}$ & $\begin{array}{l}\text { Categorization and quantification of food } \\
\text { waste at retail level; assessment of } \\
\text { environmental impact using life-cycle } \\
\text { analysis and scenario techniques }\end{array}$ & $\begin{array}{l}\text { Multiple Methods } \\
\text { - Exploratory case study based on data from a } \\
\text { Swedish supermarket } \\
\text { Quantitative data from interviews and secondary } \\
\text { data (e.g., inventory data, costs) }\end{array}$ & $\mathrm{Y}$ & $\begin{array}{c}\mathrm{Y} \\
{[\mathrm{R}]}\end{array}$ & $\mathrm{N}$ & $\mathrm{N}$ & $\begin{array}{c}\mathrm{Y} \\
{[\mathrm{SM}]}\end{array}$ & $\mathrm{Y}$ & $\mathrm{N}$ & $\mathrm{N}$ \\
\hline $\begin{array}{l}\text { Teller et al. } \\
\text { (2017) }\end{array}$ & $\begin{array}{l}\text { Assessment of in-store logistics } \\
\text { processes for products declared unsalable } \\
\text { with the aim to reduce food waste at } \\
\text { retail store level }\end{array}$ & $\begin{array}{l}\text { Mixed Methods } \\
\text { - Multiple case study across all store formats } \\
\text { - Semi-structured interviews with store } \\
\text { managers on the premises }(n=32)\end{array}$ & $\mathrm{Y}$ & $\begin{array}{c}\mathrm{Y} \\
{[\mathrm{W}]}\end{array}$ & $\mathrm{Y}$ & $\mathrm{N}$ & $\mathrm{Y}$ & $\mathrm{Y}$ & $\mathrm{N}$ & $\mathrm{N}$ \\
\hline $\begin{array}{l}\text { Aschemann- } \\
\text { Witzel (2018) }\end{array}$ & $\begin{array}{l}\text { Analysis of the impact of expiration date } \\
\text { based pricing on consumer perception of } \\
\text { and preferences for suboptimal food }\end{array}$ & $\begin{array}{l}\text { Single Method } \\
\text { Online survey experiment among consumer in } \\
\text { Denmark }(n=842)\end{array}$ & $\mathrm{Y}$ & $\begin{array}{c}\mathrm{Y} \\
{[\mathrm{C}]}\end{array}$ & $\mathrm{N}$ & $\begin{array}{c}\mathrm{Y} \\
\text { partly }\end{array}$ & $\mathrm{N}$ & $\mathrm{N}$ & $\mathrm{N}$ & $\mathrm{N}$ \\
\hline
\end{tabular}

